\title{
Characterization and Cytotoxicity of Polyprenol Lipid and Vitamin E-TPGS Hybrid Nanoparticles for Betulinic Acid and Low-Substituted Hydroxyl Fullerenol in MHCC97H and L02 Cells
}

This article was published in the following Dove Press journal:

International Journal of Nanomedicine

\author{
Ran Tao ${ }^{1,2}$ \\ Chengzhang Wang ${ }^{1,2}$ \\ Yin $\mathrm{Lu}^{3}$ \\ Changwei Zhang' \\ Hao Zhou ${ }^{1,2}$ \\ Hongxia Chen' \\ WenJun $\mathrm{Li}^{1}$
}

'Institute of Chemical Industry of Forest Products, CAF, Nanjing, Jiangsu Province 210042, People's Republic of China;

${ }^{2}$ Research Institute of Forestry New Technology, CAF, Beijing 10009I, People's Republic of China; ${ }^{3}$ General Hospital of Eastern Theater Command, Nanjing, Jiangsu Province 210002, People's

Republic of China
Correspondence: Ran Tao; Chengzhang Wang Tel +86-025-8548242I; +86-025-8548247I Email trmoon1949@163.com; wangczlhs@sina.com
Background: This study demonstrated an innovative formulation including the polyprenol (GBP) lipid and vitamin E-TPGS hybrid nanoparticles (NPs) which was aimed to control the transfer of betulinic acid (BA) and low-substituted hydroxyl fullerenol $\left(\mathrm{C}_{60}(\mathrm{OH})_{n}\right)$. Additionally, it developed BA- $\mathrm{C}_{60}(\mathrm{OH})$ n-GBP-TPGS-NPs delivery system and researched the anti-hepatocellular carcinoma (HCC) effects.

Materials and Methods: The NPs were prepared by nanoprecipitation with ultrasonicassisted emulsification (UAE) method. It was characterized by scanning electronic microscopy (SEM), transmission electron microscopy (TEM), FTIR spectrum, size distribution and zeta potential. Physical and chemical properties were evaluated through measurement of drug release, stability studies, drug loading efficiency (DE) and encapsulation efficiency (EE). Biological activities were evaluated through measurement of MTT assay, lactate dehydrogenase leakage assay (LDH), cell proliferation assays, cell apoptosis analysis, comet assay, wound healing assay, cell invasion and Western blot analysis.

Results and Conclusions: The NPs exhibited clear distribution characteristics, improved solubility and stability. BA and $\mathrm{C}_{60}(\mathrm{OH})_{\mathrm{n}}$ for the NPs displayed a biphasic release pattern with sustained drug release properties. The mixture of $\mathrm{C}_{60}(\mathrm{OH})_{\mathrm{n}}$ with different hydroxyl groups may have a certain effect on the stability of the NPs system itself. The NPs could effectively inhibit MHCC97H cell proliferation, migration and invasion in vitro. Combined use of $\mathrm{C}_{60}(\mathrm{OH})_{\mathrm{n}}$ and BA in GBP lipids may improve the inhibit effect of $\mathrm{C}_{60}(\mathrm{OH})_{\mathrm{n}}$ or BA against $\mathrm{HCC}$ cells and reduce cytotoxicity and genotoxicity of $\mathrm{C}_{60}(\mathrm{OH})_{n}$ for normal cells. We concluded that one of the important mechanisms of $\mathrm{BA}^{-\mathrm{C}_{60}}(\mathrm{OH})_{\mathrm{n}}$-GBP-TPGS-NPs inhibiting $\mathrm{MHCC} 97 \mathrm{H}$ cells is achieved by up-regulating the expression of Caspase-3, Caspase- 8 and Caspase- 9 .

Keywords: polyprenol, vitamin E-TPGS, betulinic acid, fullerenol, anti-tumor

\section{Introduction}

Hepatocellular carcinoma (HCC) is one of the frequently primary liver malignant tumors that are the most vital disease worldwide. Multiple-therapeutic approaches have been selected and provided benefits of survival on different stages of HCC. More importantly, cancer chemotherapy is the most common treatment in modern medicine development. According to the report, betulinic acid (BA), a pentacyclic triterpenoid mainly from birch, possesses a large number of pharmacological activities such as anti-oxidant, anti-malarial, anti-inflammatory, hepatoprotective, 
anthelmintic, anti-depression, anti-HIV and anti-cancer. ${ }^{1}$ It could induce tumor cell apoptosis by activating mitochondrial membrane permeability and releasing Smac, cytochrome or apoptosis. ${ }^{2}$ It is capable of leading the creation of reactive oxygen species, activate caspase sand nuclear fragmentation. ${ }^{3}$ Besides, it has attracted considerable attention to many studies on derivatives which have demonstrated promising results as chemotherapeutic agents for different types of cancers. ${ }^{4}$ However, due to the low water solubility and short half-life in the system cycle, it demonstrated incomplete anti-tumor activity. ${ }^{5}$

Due to superior biocompatibility and biodegradability, new nanocarriers have been widely focused on and applied for the drug delivery system of anti-tumor pharmaceuticals. Polyethylene glycol (PEG) conjugated pharmaceuticals for targeted cancer cell has become one of the best dosage forms for efficient chemotherapeutic agents delivery. Tocofersolan, D- $\alpha$-tocopherol polyethylene glycol 1000 succinate (Vitamin E-TPGS, TPGS), amphiphilic vitamin E derivative containing PEG 1000 is a famous drug delivery system surfactant and a drug safety adjuvant approved by FDA. TPGS contains a hydrophilic polar head and a lipophilic alkyl tail, which increases apparent solubility and stability of some unstable drugs. ${ }^{6}$ It has beneficial solubilisation effects, which improve the oral bioavailability of certain liposoluble anti-cancer drugs and inhibit P-glycoprotein (P-gp)-mediated multi-drug resistance (MDR) to improve tumor cells permeability. ${ }^{7}$ TPGS possesses selective cytotoxic effects and induces anti-cancer cell apoptosis, which can be linked with other chemotherapeutic drugs to improve therapeutic efficiency and reduce side effects. The selective apoptosis systems of TPGS-mediated cancer cells are complex, mainly including reactive oxygen species (ROS) inducers, downregulation of anti-apoptotic proteins and DNA damage. ${ }^{8}$ Therefore, we believe that TPGS could increase the solubility and the bioavailability of BA, and even improve therapeutic efficiency and reduce side effects.

Polyprenol (PP) is an important lipid with high biological activity in the form of homologues and widely present in organisms. Ginkgo biloba Leaves polyprenol (GBP) is a liposoluble component generally consisting of 15 to 21 unsaturated isoprene units. ${ }^{9}$ GBP could selectively increase the intracellular accumulation of chemotherapeutic drugs and the cytotoxins in MDR-related tumor cells. Therefore, GBP is expected to become a promising MDR modulator and synergist. ${ }^{10}$ Besides, GBP shows broad prospects in the treatment of Hepatocellular carcinoma
(HCC). We reported that it had significantly inhibitory effect of graphene oxide and folate coupled chitosan nanocomposites loaded with GBP and fullerene $\mathrm{C}_{60}$ on MHCC97H cells. GBP has a good synergistic effect in inhibiting the proliferation of MHCC $97 \mathrm{H}$ cells. ${ }^{11}$ The previous research implied that polypentadiene lipids could greatly increase the permeability and fluidity of cell membrane. ${ }^{12}$ The addition of TPGS mixed lipids can be implemented in drug delivery systems (DDS), such as liposomes, solid lipid NPs, and self-microemulsifying DDS to improve solubility, anti-cancer efficacy, MDRinhibiting capacity, oral absorption and even could be delivered as a targeted bridge. ${ }^{13}$ According to our expectations, novel core-shell type nanopreparation based on lipid (GBP) and TPGS may have better therapeutic effects than conventional TPGS preparations.

Fullerene $\mathrm{C}_{60}\left(\mathrm{C}_{60} \mathrm{~F}\right)$ is an important type of nanomaterial, which has attracted wide attention due to its specific structure, unique physical, chemical and electric properties. This indicates that $\mathrm{C}_{60} \mathrm{~F}$ and its derivatives have a high efficiency in inhibiting tumor cell growth compared with ordinary anti-tumor pharmaceuticals. ${ }^{14}$ It is worth noting that fullerenol $\left(\mathrm{C}_{60}\right.$ $(\mathrm{OH})_{\mathrm{n}}$ ) is a water-soluble original $\mathrm{C}_{60} \mathrm{~F}$, which is rich in hydroxyl groups and could efficiently inhibit the growth and metastasis of transplanted malignant tumor. ${ }^{15}$ The number of $\mathrm{OH}$ groups in fullerenol is a critical factor in interacting with cell membranes. Fullerenol has more hydroxyl groups to bring better water solubility, but its strong hydrophilicity hinders its penetration on full-fat soluble cell membranes, ${ }^{16}$ thereby reducing its biological activity. ${ }^{17}$ TPGS can dissolve water-soluble stages of $\mathrm{C}_{60} \mathrm{~F}$ in by dissolving of the core of $\mathrm{C}_{60} \mathrm{~F}$ spherical micelles. ${ }^{18}$ Therefore, we hope to use TPGS and GBP to mix different amounts of low-substituted hydroxyl fullerenol and BA to enhance the cell membrane permeability and expect to improve its biological activity.

HCC metastasis is the main cause of liver cancer mortality, and little is known about the effect on the HCC metastasis. Therefore, the focus on early work is to investigate and understand the etiopathogenesis and molecular treatment of HCC metastasis. We believe that the polyprenol lipids and vitamin E-TPGS hybrid nanoparticles (NPs) are applied to control the release of betulinic acid and low-substituted hydroxyl fullerenol $\left(B A-\mathrm{C}_{60}\right.$ $(\mathrm{OH})_{\mathrm{n}}$-GBP-TPGS-NPs) is a novel and promising approach to disrupt the process of migration or invasion, and even curb tumor growth and metastasis. BA and GBP cannot be directly dispersed in water. While BA and GBP are the loaded drugs in NPs, which are dispersed in, 
molten TPGS. This study involves the preparation of BA- $\mathrm{C}_{60}(\mathrm{OH})_{\mathrm{n}}$-GBP-TPGS-NPs by nanoprecipitation ${ }^{18,19}$ and ultrasonic-assisted emulsification (UAE) ${ }^{20}$ method. We specifically selected MHCC97H cell line (a highly metastatic HCC cell line) as an experimental model, and this highly metastatic nature of MHCC97H cell may help us to obtain more information about the mechanism of HCC metastasis than ordinary HCC cells. We believe that the prepared NPs may have a better effect on MHCC $97 \mathrm{H}$ cells than single BA or $\mathrm{C}_{60}(\mathrm{OH})_{\mathrm{n}}$.

\section{Materials and Methods Materials}

BA (HPLC, contents over 97.0\%), TPGS (average molecular weight of 1513) and Triton X-100 purchased from Aladdin Chemical Company (Shanghai, China). $\mathrm{C}_{60}(\mathrm{OH})_{\mathrm{n}}$ $(\mathrm{n}=2-6, \mathrm{n}=10-14$ and $\mathrm{n}=16-20)$ purchased from Tanfeng Company (Suzhou, China). GBP (HPLC, $\mathrm{C}_{70}-\mathrm{C}_{120}$, contents over 99.0\%) separated and purified from Ginkgo biloba Leaves in September 2018, Sichuan Province, China.

\section{Preparation of TPGS Solution}

Two percent TPGS aqueous solutions were produced by the dissolution of $2.0 \mathrm{~g}$ TPGS (m.p. $=38-41^{\circ} \mathrm{C}$ ) on a hot plate and the hydration of the melt with $98 \mathrm{~mL}$ hot nanopure water in $50^{\circ} \mathrm{C}$ constant whisking. The TPGS with water mixture was whisked for more than 6 hours and cooled until indoor temperature. The resulting TPGS aqueous solution was colourless and steady at indoor temperature for a few days. It was continued to dilution by nanopure water to $0.05 \%$ before application.

\section{Preparation of $\mathrm{C}_{60}(\mathrm{OH})_{\mathrm{n}}$-TPGS Dispersion Mixture}

$\mathrm{C}_{60}(\mathrm{OH})_{\mathrm{n}}$ (mixture with $\mathrm{n}=2-6, \mathrm{n}=10-14$ and $\mathrm{n}=16-20$, $1: 1: 1, w / w / w)$ was added to TPGS melt in a water bath.
After $2 \mathrm{~h}$ the brown mixture was hydrated with hot nanopure water about $50^{\circ} \mathrm{C}$ with constant stirring and cooled until room temperature. After $0.22 \mu \mathrm{m}$ filtration both the $\mathrm{C}_{60}(\mathrm{OH})_{\mathrm{n}}$-TPGS solutions (containing total of $10 \mathrm{mg} / \mathrm{mL}$ $\mathrm{C}_{60}(\mathrm{OH})_{\mathrm{n}}$ mixture) are clear orange and steady at indoor temperature for a few days.

\section{Preparation of BA- $\mathrm{C}_{60}(\mathrm{OH})_{\mathrm{n}}$-GBP-TPGS- NPs}

Both BA and different weights (Table 1) of GBP were, respectively, added and dissolved in ethyl acetate (containing $10 \mathrm{mg} / \mathrm{mL} \mathrm{BA}$ ). The mixture of BA and GBP solution to ethyl acetate and the prepared $\mathrm{C}_{60}(\mathrm{OH})_{\mathrm{n}}$-TPGS dispersion mixture $(1: 10, \mathrm{v} / \mathrm{v})$ were hydrated with hot nanopure water under constant magnetic stirring overnight to remove the organic solvent. Later, the $B A-\mathrm{C}_{60}(\mathrm{OH})_{\mathrm{n}^{-}}$ GBP-TPGS-NPs formed were harvested with a predetermined high speed $(15,000 \mathrm{r} / \mathrm{min})$ by high-speed agitator (IKA-WERK, ultra Turrax, T25 basic, Staufen, Germany) for $30 \mathrm{~min}$ in constantly indoor temperature. Meanwhile, it was assisted by ultrasonic through the use of a disrupter horn hooked up Sonifier (50\% amplitude and $10 \%$ pulsation) were used with $10 \mathrm{~min}$ at $30 \sim 40{ }^{\circ} \mathrm{C}$. The NPs were cleansed with water, recentrifuged and kept in vacuum dryers at $4^{\circ} \mathrm{C}$ to further assessments.

\section{Characterization of $B A-\mathrm{C}_{60}(\mathrm{OH})_{n}-\mathrm{GBP}-$ TPGS-NPs}

Scanning electronic microscopy (SEM) was applied to measure the morphologies of BA- $\mathrm{C}_{60}(\mathrm{OH})_{\mathrm{n}}$-GBP-TPGSNPs: the freezing-dry NPs were directly cast into a fixed sliding glass. After drying at indoor temperature, the samples were processed under high vacuum and examined with an electron microscopy (JSM-6010LA, Japan). For in-situ liquid cell transmission electron microscopy (TEM)

Table I Characterization of NPs Preparations

\begin{tabular}{|c|c|c|c|c|c|c|c|c|}
\hline $\begin{array}{l}\text { NPs } \\
\text { Preparations }\end{array}$ & $\begin{array}{l}\text { GBP } \% \\
\text { of TPGS }\end{array}$ & $\begin{array}{l}\text { Mean } \\
\text { Particle } \\
\text { Size }(\mathbf{n m})\end{array}$ & $\begin{array}{l}\text { Mean Zeta } \\
\text { Potential } \\
(\mathrm{mV})\end{array}$ & $\begin{array}{l}\text { Polydispersity } \\
\text { Index (PDI) }\end{array}$ & $\begin{array}{l}\text { BA Loading } \\
\text { Efficiency } \\
\text { (\%) }\end{array}$ & $\begin{array}{l}\text { BA } \\
\text { Encapsulation } \\
\text { Efficiency (\%) }\end{array}$ & $\begin{array}{l}\mathrm{C}_{60}(\mathrm{OH})_{\mathrm{n}} \\
\text { Loading } \\
\text { Efficiency (\%) }\end{array}$ & $\begin{array}{l}\mathrm{C}_{60}(\mathrm{OH})_{\mathrm{n}} \\
\text { Encapsulation } \\
\text { Efficiency (\%) }\end{array}$ \\
\hline Batch A & $1 \%$ & $226.9 \pm 26.8 a$ & $-7.05 \pm 0.58 a$ & $0.3 \mathrm{II} \pm 0.0 \mathrm{IIa}$ & $2.489 \pm 0.014 a$ & $47.8 \mathrm{I} \pm 2.4 \mathrm{Ia}$ & $2.450 \pm 0.02 \mathrm{la}$ & $46.32 \pm 3.43 a$ \\
\hline Batch B & $5 \%$ & $229.2 \pm 23.1 \mathrm{a}$ & $-7.04 \pm 0.62 \mathrm{a}$ & $0.305 \pm 0.010 \mathrm{a}$ & $3.449 \pm 0.042 b$ & $57.96 \pm 3.94 b$ & $3.35 \mathrm{I} \pm 0.018 \mathrm{~b}$ & $54.04 \pm 5.04 b$ \\
\hline Batch C & $10 \%$ & $220.4 \pm 22.0 \mathrm{a}$ & $-6.98 \pm 0.53 a$ & $0.279 \pm 0.012 b$ & $4.695 \pm 0.119 c$ & $66.89 \pm 4.09 c$ & $4.620 \pm 0.322 c$ & $64.38 \pm 2.52 c$ \\
\hline Batch D & $15 \%$ & $205.5 \pm 20.5 b$ & $-6.84 \pm 0.69 b$ & $0.255 \pm 0.009 c$ & $7.03 \mathrm{I} \pm 0.252 \mathrm{~d}$ & $80.05 \pm 6.56 d$ & $6.878 \pm 0.427 d$ & $80.02 \pm 3.67 d$ \\
\hline Batch $E^{*}$ & $20 \%$ & $191.1 \pm 21.2 c$ & $-6.80 \pm 0.78 b$ & $0.25 \mathrm{I} \pm 0.02 \mathrm{lc}$ & $9.059 \pm 0.598 \mathrm{e}$ & $92.89 \pm 5.2 \mathrm{le}$ & $8.013 \pm 0.612 \mathrm{e}$ & $86.58 \pm 2.59 e$ \\
\hline Batch F & $25 \%$ & $231.0 \pm 25.7 a$ & $-6.59 \pm 0.65 c$ & $0.264 \pm 0.015 d$ & $8.772 \pm 0.76 \mathrm{If}$ & $90.97 \pm 2.43 \mathrm{e}$ & $7.84 I \pm 0.389 e$ & $84.90 \pm 4.47 e$ \\
\hline Batch G & $30 \%$ & $359.8 \pm 31.1 d$ & $-6.62 \pm 0.32 c$ & $0.238 \pm 0.018 \mathrm{e}$ & $8.00 \mathrm{I} \pm 0.53 \mathrm{lg}$ & $85.10 \pm 4.65 f$ & $7.08 I \pm 0.627 d$ & $78.95 \pm 2.25 d$ \\
\hline
\end{tabular}

Notes: Data are expressed as mean \pm SD $(n=3)$. * Optimized batch was batch $E\left(20 \%\right.$ GBP of TPGS, w\%). GBP: BA: $\mathrm{C}_{60}(\mathrm{OH})_{\mathrm{n}}$ ratio $\left(2: 1: 1\right.$, w/w/w). $\mathrm{C}_{60}(\mathrm{OH})_{\mathrm{n}}(\mathrm{mixture}$ with $n=2-6, n=10-14$ and $n=16-20,1: 1: 1, w / w / w)$. Values not sharing the equal letter are obviously diverse from each other ( $P<0.05$ ANOVA ensued by the Tukey's test). 
experiments, the NP solutions were dispersed in solution of Triton X-100 (1\%) with pure water. And NP solution was then loaded into liquid cell scaffold and examined with an electron microscopy (JEM-2200FS, Japan). The FTIR samples were prepared by integration of a small amount of samples of $100 \mathrm{mg}$ potassium bromides, which was then condensed to crystal panel. FTIR spectrum was attained by scanning in the range from $4000 \sim 400 \mathrm{~cm}^{-1}$ on an FTIR instrument (GX-1, USA). Size distribution and zeta potentiometry (Nano-ZS90, UK): the prepared nanoemulsion (the prepared NPs mixed with Triton X-100 dispersed in water) was diluted 100 times with pure water. Mensuration of size distribution of the specimen was assayed in the scope of 0.1 5000 $\mathrm{nm}$ at indoor temperature. Mensuration of zeta potential for the specimen was metered using photodiode detectors at room temperature.

\section{Drug Loading Efficiency (DE) and Encapsulation Efficiency (EE) of BA- $\mathrm{C}_{60}$ $(\mathrm{OH})_{\mathrm{n}}$-GBP-TPGS-NPs}

DE and EE of BA- $\mathrm{C}_{60}(\mathrm{OH})_{\mathrm{n}}$-GBP-TPGS-NPs were determined in accordance with the reported method. ${ }^{21,22} \mathrm{~A}$ certain amount of the NPs was made into powder, extracted with $\mathrm{n}$-hexane for $24 \mathrm{~h}$, and then an external standard method was applied to confirm the concentration of supernatant medical BA and $\mathrm{C}_{60}(\mathrm{OH})_{\mathrm{n}}$ by HPLC. ${ }^{23-25} \mathrm{DE}$ and EE of NPs were calculated in accordance with the following formula.

$$
\begin{aligned}
& \text { Drug loading efficiency }(\%)=\frac{\mathrm{W}_{1}}{\mathrm{~W}_{\mathrm{m}}} \times 100 \% \\
& \text { Encapsulation efficiency }(\%)=\frac{\mathrm{W}_{\mathrm{l}}}{\mathrm{W}_{\mathrm{a}}} \times 100 \%
\end{aligned}
$$

$\mathrm{W}_{1}$ is the weight of loading $\mathrm{BA}$ or $\mathrm{C}_{60}(\mathrm{OH})_{\mathrm{n}}$, while $\mathrm{W}_{\mathrm{m}}$ is the weight of NPs, and $\mathrm{W}_{\mathrm{a}}$ is the originally added weight of BA or $\mathrm{C}_{60}(\mathrm{OH})_{\mathrm{n}}$. In the DE and EE studies, the results of three diverse samples were averaged and displayed as the mean \pm standard deviation (SD).

\section{Drug Release of $B A-\mathrm{C}_{60}(\mathrm{OH})_{n}-\mathrm{GBP}$ - TPGS-NPs}

Drug release from the $B A-\mathrm{C}_{60}(\mathrm{OH})_{\mathrm{n}}$-GBP-TPGS-NPs in phosphate buffer solution (PBS) was simulated in intestinal fluid ( $\mathrm{pH}$ 7.4) and simulated the extracellular tumor environment ( $\mathrm{pH} 6.5$ ). Briefly, a $5 \mathrm{mg}$ of NPs sample was suspended in $5 \mathrm{~mL}$ PBS (pH 7.4) and continuously stirred at $37{ }^{\circ} \mathrm{C}$. After incubation, $2.5 \mathrm{~mL}$ of the supernatant was removed and the equal volume of PBS was replaced. All data were measured by HPLC method, ${ }^{21-23}$ and the release rate was calculated as follows:

$$
\text { Release rate }(\%)=\frac{\sum_{i}^{n} C_{i} V_{0}}{M} \times 100 \%
$$

$\mathrm{V}_{0}$ is the cleared volume of the release media, $\mathrm{C}_{\mathrm{i}}$ is the certain concentration of released $\mathrm{BA}$ or $\mathrm{C}_{60}(\mathrm{OH})_{\mathrm{n}}$, and $\mathrm{M}$ is the total mass of $\mathrm{BA}$ or $\mathrm{C}_{60}(\mathrm{OH})_{\mathrm{n}}$ of specimen. In the evaluation of drug release, the results of three various specimens were averaged and were displayed as SD.

\section{Stability Studies}

Stability studies during storage (mean size and PDI) at $25^{\circ}$ C within 0 30 days were performed on aliquots. Stability studies in simulated media (mean size) were performed at $0 \sim 24 \mathrm{~h}$ in simulated intestinal fluid $(\mathrm{pH} 7.4)$ and in the simulated extracellular tumor environment $(\mathrm{pH} 6.5)$ at $37^{\circ} \mathrm{C}$. The results were displayed when three independently measured SDs were performed.

\section{Cell Culture}

The human HCC cell species MHCC97H and normal human hepatic cell species L02 with high metastatic potential were purchased from Shanghai Cancer Institute (China). The cells were cultured in DMEM, penicillinstreptomycin $(10,000 \mathrm{U} / \mathrm{mL})$ (Thermo Fisher Scientific, USA), plated at $10^{4}$ cells and incubated at $37^{\circ} \mathrm{C}$. Culture the cells until they achieved in the logarithmic growth phase.

\section{Cytotoxicity of BA- $\mathrm{C}_{60}(\mathrm{OH})_{n}$-GBP-TPGS -NPs}

The cytotoxicity of MHCC97H and L02 cells was assessed by advanced $\mathrm{MTT}^{26}$ and lactate dehydrogenase leakage test $(\mathrm{LDH}){ }^{27}$ The samples were $\mathrm{BA}-\mathrm{C}_{60}(\mathrm{OH})_{\mathrm{n}}$-GBPTPGS-NPs (BA or $\mathrm{C}_{60}(\mathrm{OH})_{\mathrm{n}}$ concentration: $1,2.5,5,10$, $25,50 \mu \mathrm{g} / \mathrm{mL}$ and GBP concentration is double the concentration of BA or $\mathrm{C}_{60}(\mathrm{OH})_{\mathrm{n}}$, BA-TPGS solution (BA concentration same as NPs), $\mathrm{C}_{60}(\mathrm{OH})_{\mathrm{n}}$-TPGS dispersion $\left(\mathrm{C}_{60}(\mathrm{OH})_{\mathrm{n}}\right.$ concentration same as NPs), GBP-TPGS solution (GBP concentration same as NPs). TPGS solution (without supplementary BA, GBP or $\mathrm{C}_{60}(\mathrm{OH})_{\mathrm{n}}$ ) was treated as the negative control, while cis-diamino-dichloroplatinum (II) (cisplatin, CDDP) was the positive control. For MTT analysis, an additional $100 \mu \mathrm{L}$ aliquot of culture media (including the test samples) were added to $0.2 \%$ DMSO and then incubated for 3 days. The cells were 
stained with MTT (3-(4,5-dimethylthiazol-2-yl)-2,5-diphenyl tetrazolium bromide), and the absorbance was measured at $550 \mathrm{~nm}$. $\mathrm{IC}_{50}$ values were measured as the concentrations of drugs or samples required to achieve $50 \%$ cytostatic inhibition. To detect the morphology of sample-treated cells, the cells were pre-seeded on the coverslips at a density of $2 \times 10^{4}$ cells $/ \mathrm{mL}$, and placed at $37{ }^{\circ} \mathrm{C}$ in a $5 \% \mathrm{CO}_{2}$ atmosphere for $24 \mathrm{~h}$. The sample solutions were added with different concentrations and then incubated for $24 \mathrm{~h}$. After treatment and measurement as depicted above, the cells were fixed in containing $1 \%$ paraformaldehyde in PBS. The statistics were presented as the percentage of viable cells relative to the control group (control group: untreated cells with 100\% viability). Relative inhibition ratio ( $\mathrm{R} \%$ ) was calculated in accordance with formula (1). The statistics were expressed as the mean $\pm \mathrm{SD}$ of three separate measurements.

$$
\mathrm{R} \%=\left(1-\frac{\text { Absorbance }_{\text {test }}}{\text { Absorbance }_{\text {control }}}\right) \times 100 \%
$$

The LDH activity was assayed in $3.0 \mathrm{~mL}$ of reactant mixture containing $100 \mu \mathrm{L}$ of pyruvate $(2.5 \mathrm{mg} / \mathrm{mL}$ phosphate buffer) and $100 \mu \mathrm{L}$ of NADH $(2.5 \mathrm{mg} / \mathrm{mL}$ phosphate buffer). The remaining volume was modulated with phosphate buffer $(0.1 \mathrm{M}, \mathrm{pH}$ 7.4).The oxygenation rate of NADH was measured by the use of a Varioskan Flash spectral scanning multimode reader (Thermo Fisher, USA) at $25^{\circ} \mathrm{C}, 1 \mathrm{~min}$ intervals at $340 \mathrm{~nm}$ for $3 \mathrm{~min}$. The released LDH data is presented as LDH activity in media. All data were presented as the mean $\pm \mathrm{SD}$ of three independent measurements.

\section{Cell Proliferation Assays and Cell Apoptosis Analysis}

The concentrations of MHCC97H and $\mathrm{L} 02$ cells treated with BA- $\mathrm{C}_{60}(\mathrm{OH})_{\mathrm{n}}$-GBP-TPGS-NPs $\left(\mathrm{BA}\right.$ or $\mathrm{C}_{60}(\mathrm{OH})_{\mathrm{n}}$ concentration: $1,2.5,5,10,25,50 \mu \mathrm{g} / \mathrm{mL}$ and GBP concentration is double the concentration of $\mathrm{BA}$ or $\mathrm{C}_{60}(\mathrm{OH})_{\mathrm{n}}$, BA-TPGS solution (BA concentration is the same as NPs), $\mathrm{C}_{60}(\mathrm{OH})_{\mathrm{n}}$-TPGS dispersion $\left(\mathrm{C}_{60}(\mathrm{OH})_{\mathrm{n}}\right.$ concentration $)$ same as NPs), GBP-TPGS solution (GBP concentration is the same as NPs). TPGS solution was the negative control while cis-diamino-dichloro-platinum (II) (cisplatin, CDDP) was the positive control. They harvested 48 hands and gathered. Cell proliferation was determined with the colony formation cell assay. Approximately 500 cells were added into the plate and preserved in DMEM (10\% FBS). Colonies were fixed with $\mathrm{MeOH}$ and stained with $0.1 \%$ crystal violet in PBS. The colony development was determined by counting the number of stained colonies. Flow cytometry for cell apoptosis analysis: FITC Annexin V and PI were double-stained with FITC Annexin V Apoptosis Detection Kit (BD Biosciences), and a flow cytometry (FACScan ${ }^{\circledR}$, BD Biosciences) investigated the cells supplied from a Cell Quest software (BD Biosciences). The relative ratio of early apoptotic cells in each test was compared to the comparative transfectant. The results were presented as the mean $\pm \mathrm{SD}$ of three separate measurements.

\section{Comet Assay}

The comet assay is a technique that identifying genotoxicity by detecting DNA strand damage. ${ }^{28}$ Nearly $7 \times 10^{4}$ cells/well were seeded in the plate. After seeding, MHCC97H and L02 cells were disposed with BA- $\mathrm{C}_{60}$ $(\mathrm{OH})_{\mathrm{n}}$-GBP-TPGS-NPs $\left(\mathrm{BA}\right.$ or $\mathrm{C}_{60}(\mathrm{OH})_{\mathrm{n}}$ concentrations: $1,2.5,5,10,25,50 \mu \mathrm{g} / \mathrm{mL}$ and GBP concentrations are double the concentration of BA or $\left.\mathrm{C}_{60}(\mathrm{OH})_{n}\right)$, BA-TPGS solution (BA concentrations are the same as NPs), $\mathrm{C}_{60}$ $(\mathrm{OH})_{\mathrm{n}}$-TPGS dispersion fluid $\left(\mathrm{C}_{60}(\mathrm{OH})_{\mathrm{n}}\right.$ concentrations are the same as NPs), GBP-TPGS solution (GBP concentrations are the same as NPs). The positive control was tert-butyl hydroperoxide $(50 \mathrm{mg} / \mathrm{mL})$ and the negative control is TPGS solution. After treatment with the samples, the cells were trypsinized and resuspended in DMEM, and the cell suspension was centrifuged. The cells were suspended in PBS for comet assay. Approximately $5 \mu \mathrm{L}$ of cell suspension (about $10^{4}$ cells) was mixed with $95 \mu \mathrm{L}$ of $0.5 \%$ agarose (low melting point), stratified at the end of the normal slide, and precoated with $200 \mu \mathrm{L} 1 \%$ normal agarose. After that, it was overlapped with a third layer containing $100 \mu \mathrm{L}$ of $0.5 \%$ agarose. Then, the slides were immersed in the lysis solution $(\mathrm{pH} \mathrm{10)}$ for $12 \mathrm{~h}$. The slides were immersed in a electrophoresis solution $(\mathrm{pH} \geq 13)$ for $15 \mathrm{~min}$. Electrophoresis was performed at $15 \mathrm{~V}$ for $15 \mathrm{~min}$. The slides were neutralized with tris buffer at $\mathrm{pH} 7.5$, which was treated with $20 \mu \mathrm{g} / \mathrm{mL}$ bromoethyl stain and then retain until scoring. By using a light analysis system (Comet assay IV) attached to a fluorescence microscope (Nikon Ts2R-FL), place slides at 400x magnification for analysis. The percentage of DNA in the tail and tail moment were detected and measured as comet parameters. Pictures of 100 stochastic cells were validated for each test. All values were attained from the mean of three individual tests: 200 cells totally per concentration. 


\section{Wound Healing Assay}

The migration ability of MHCC97H cells was tested by the wound healing assay. ${ }^{29} \mathrm{MHCC} 97 \mathrm{H}$ cells were seeded on $0.1 \%$ gelatin-coated plates until they reached $80 \%$ confluence and then incubated with $10 \mu \mathrm{g} / \mathrm{mL}$ mitomycin $\mathrm{C}$ to inactivate the cells. The cell monolayer was scraped off with a sterile micropipette tip and washed with PBS. After that, the medium was replaced with fresh medium, including TPGS solution (negative control), $B A-\mathrm{C}_{60}(\mathrm{OH})_{\mathrm{n}}$ -GBP-TPGS-NPs $\left(B A\right.$ or $\mathrm{C}_{60}(\mathrm{OH})_{\mathrm{n}}$ concentration: 1, 2.5, $5,10,25,50 \mu \mathrm{g} / \mathrm{mL}$ and GBP concentration is double the concentration of BA or $\mathrm{C}_{60}(\mathrm{OH})_{\mathrm{n}}$, BA-TPGS solution (BA concentration is the same as NPs), $\mathrm{C}_{60}(\mathrm{OH})_{\mathrm{n}}$-TPGS dispersion $\left(\mathrm{C}_{60}(\mathrm{OH})_{\mathrm{n}}\right.$ concentration) same as NPs), GBPTPGS solution (GBP concentration is the same as NPs). After 24 hours of incubation with an inverted microscope (Nikon Ts2R-FL), the wound closure was recorded and photographed. Wound closure was detected and measured by microscope software, and the inhibitory effect was expressed as a percentage of the control group, which was set to $100 \%$. Migrated units were photographed and counted in five randomly selected fields.

\section{Cell Invasion}

To assess the invasion of MHCC97H cells, the cells were analyzed using the xCELLigence ${ }^{\circledR}$ DP system (ACEA Biosciences) and CIM-16 plates. $^{30}$ The cell index increased when cells invaded the cell membrane from the top-down chamber under the action of a chemical attractant containing $10 \%$ serum and adhered to the electronic sensor on the other side of the membrane. Before the experiment, the membrane of the upper chamber was covered with $30 \mu \mathrm{L}$ matrigel, and the matrix was dehydrated in a serum-free medium at a ratio of 1:40. After seeding into the upper chamber, MHCC $97 \mathrm{H}$ cells were starved for 24 hours in serum-free medium. Ten percent serum was added to the lower chamber as a migration attractant. Allow cells to remain for 30 minutes, then add different samples including TPGS solution (negative control), BA- $\mathrm{C}_{60}(\mathrm{OH})_{\mathrm{n}}$-GBP-TPGS-NPs $\left(\mathrm{BA}\right.$ or $\mathrm{C}_{60}(\mathrm{OH})_{\mathrm{n}}$ concentration: $1,2.5,5,10,25,50 \mu \mathrm{g} / \mathrm{mL}$ and GBP concentration is double the concentration of $\mathrm{BA}$ or $\mathrm{C}_{60}(\mathrm{OH})_{\mathrm{n}}$, BA-TPGS solution (BA concentration is the same as NPs), $\mathrm{C}_{60}(\mathrm{OH})_{\mathrm{n}}$-TPGS dispersion $\left(\mathrm{C}_{60}(\mathrm{OH})_{\mathrm{n}}\right.$ concentration) same as NPs), GBP-TPGS solution (GBP concentration is the same as NPs). After 24 hours of treatment, invading cells were photographed and counted in 5 randomly selected areas.

\section{Reverse Transcription-Quantitative Polymerase Chain Reaction (RT-qPCR)}

MHCC 97H cells were seeded into the plate at a density of about $5 \times 10^{5}$ cells/well, cultured overnight, and then disposed of with BA- $\mathrm{C}_{60}(\mathrm{OH})_{\mathrm{n}}$-GBP-TPGS having various BA concentrations $(1,10,50 \mu \mathrm{g} / \mathrm{mL})$ and $\mathrm{C}_{60}(\mathrm{OH})_{\mathrm{n}}$ concentration $(1$, $10,50 \mu \mathrm{g} / \mathrm{mL})$ for 12 hours. The entire RNA of BA- $\mathrm{C}_{60}(\mathrm{OH})_{\mathrm{n}^{-}}$ GBP-TPGS-NPs treated cells was isolated by using Trizol reagent. RT-qPCR reactions were performed using $2 \mu \mathrm{g}$ of total RNA and a reversible auxiliary first-strand cDNA synthesis kit (BD Biosciences) according to the manufacturer's specifications. Amplification conditions were as follows: predenaturation at $94^{\circ} \mathrm{C}$ for 5 minutes, followed by 30 amplification cycles $\left(94^{\circ} \mathrm{C}\right.$ for $50 \mathrm{~s}, 60^{\circ} \mathrm{C}$ for $40 \mathrm{~s}$, and $72{ }^{\circ} \mathrm{C}$ for $50 \mathrm{~s}$ ), and then extension at $72{ }^{\circ} \mathrm{C}$ for 10 minutes (in ABI 7300 Thermo cycler (Applied Biosystems)), Living technology). The specific primer sequences in each gene are as follows: caspase-3, 5-GGTATTGAGACAGACAGTGG-3 (forward), and 5-CATGGGATCTGTTTCTTTGC-3 (reverse); caspase8, 5'-GATGAGGCAGACTTTCTGCT-3' (forward) and 5'CATAGTTCACGCCAGTCAGGAT-3' (reverse) and caspase-9, 5'-CATTTCATGGTGGAGGTGAAG-3' (forward) and 5'-GGGAACTGCAGGTGGCTG-3' (reverse). Data analysis was performed by using the $2^{-\Delta \Delta \mathrm{Ct}}$ metric. ${ }^{31}$ The samples were normalized for $\beta$-actin and used as an endogenous control.

\section{Western Blot Analysis}

In order to study the effects of $B A-\mathrm{C}_{60}(\mathrm{OH})_{\mathrm{n}}$-GBP-TPGSNPs on migration and invasion-related signal pathways, MHCC97H cells were treated on $\mathrm{BA} / \mathrm{C}_{60}(\mathrm{OH})_{\mathrm{n}}$ (concentrations: $1,10,50 \mu \mathrm{g} / \mathrm{mL}$ ) for 24 hours and then that were collected for Western blot analysis. An equal amount of 35 $\mu \mathrm{g}$ of protein lysate was separated by $10 \%$ SDS-PAGE and transferred to a nitrocellulose membrane. The following antibodies were used: caspase-3, caspase- 8 , caspase- 9 and $\beta$ actin (Cell Signaling Technology, Inc. Danvers, MA, USA).

\section{Results \\ Characterization of $B A-\mathrm{C}_{60}(\mathrm{OH})_{n}-\mathrm{GBP}-$ TPGS-NPs}

In this study, BA- $\mathrm{C}_{60}(\mathrm{OH})_{\mathrm{n}}$-GBP-TPGS-NPs were prepared by nanoprecipitation using the UAE method (Figure 1). The small particle size of NPs is achieved by 
homogenization and then ultrasonic treatment. NPs are characterized by SEM (Figure 2A), TEM (Figure 2B) and size distribution (Figure 2D). In the SEM, NPs are spherical, with uneven and abnormal surfaces, close to 140 to $250 \mathrm{~nm}$. In addition, due to sample processing (high vacuum), a small portion of TPGS was evenly distributed on the surface of the NPs, and some of them shrank. Therefore, in order to maximize the recovery of the original form of NPs in the solution system, it is necessary to analyze the in situ liquid cell TEM. In TEM, the NPs in solution are more uniform than the dry NPs in SEM. The structure of the inner and outer layers of the NPs is obvious, with a dark black circle in the particles (indicated by the red arrow). By obtaining each data from Table 1, we found that Batch $\mathrm{E}$ had the best average size $(191.1 \pm 21.2$ $\mathrm{nm})$ and PdI $(0.251 \pm 0.021)$, and the average zeta potential was $-6.80 \pm 0.78 \mathrm{mV}$. The size and zeta potential of the optimized NPs were in the range of $140.2 \sim 258.4 \mathrm{~nm}$, and in the range of $-23.14 \sim 16.66 \mathrm{mV}$. FTIR analysis (Figure 2C): The characteristic peaks of NPs such as $\mathrm{C}-\mathrm{O}$ at $1132 \mathrm{~cm}^{-1}$ were detected from FTIR tensile vibration at, asymmetric bending vibration of $\mathrm{CH}_{3}$ at $1351 \mathrm{~cm}^{-1}$, asymmetric bending vibration of $\mathrm{CH}_{2}$ at $1425 \mathrm{~cm}^{-1}, \mathrm{C}=\mathrm{O}$ tensile vibration at $1602 \mathrm{~cm}^{-1}$, the tensile vibration of C-H at $2891 \mathrm{~cm}^{-1}$ and the tensile vibration of $\mathrm{O}-\mathrm{H}$ at $3409 \mathrm{~cm}^{-1}$. Compared with the infrared absorption peaks of hydroxyl groups in other samples (especially TPGS), the hydroxyl peaks of NPs have a slight blue shift.

\section{Drug Loading Efficiency and Encapsulation Efficiency}

Efficiency of medicine delivery lies on encapsulation efficiency, also known as drug loading efficiency. It is a significant parameter for the batch optimization procedure. With the obtainment of per data from Table 1, we discovered that batch $\mathrm{E}$ has the best encapsulation efficiency (BA, 92.89\% $\left.\pm 5.21 \%, \mathrm{C}_{60}(\mathrm{OH})_{\mathrm{n}}, 86.58 \% \pm 2.59 \%\right)$ and drug loading efficiency (BA, 9.059\% $\pm 0.598 \%, \mathrm{C}_{60}(\mathrm{OH})_{\mathrm{n}}, 8.013 \% \pm 0.612 \%$ ). The loading efficiency of both $\mathrm{BA}$ and $\mathrm{C}_{60}(\mathrm{OH})_{n}$ could be large to the best of the ability and meanwhile the encapsulation efficiency of both BA and $\mathrm{C}_{60}(\mathrm{OH})_{\mathrm{n}}$ could be over $85 \%$.

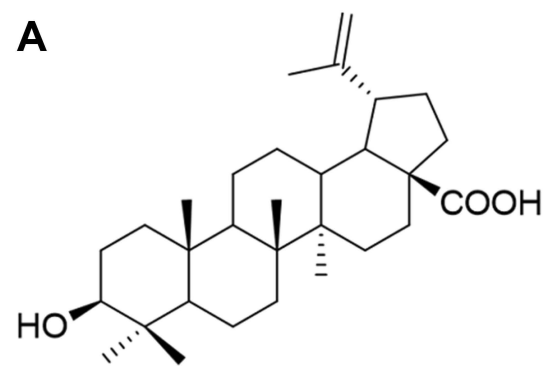

BA: Betulinic acid

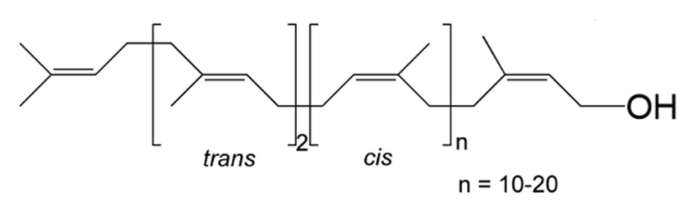

GBP: Ginkgo Biloba Leaves polyprenol
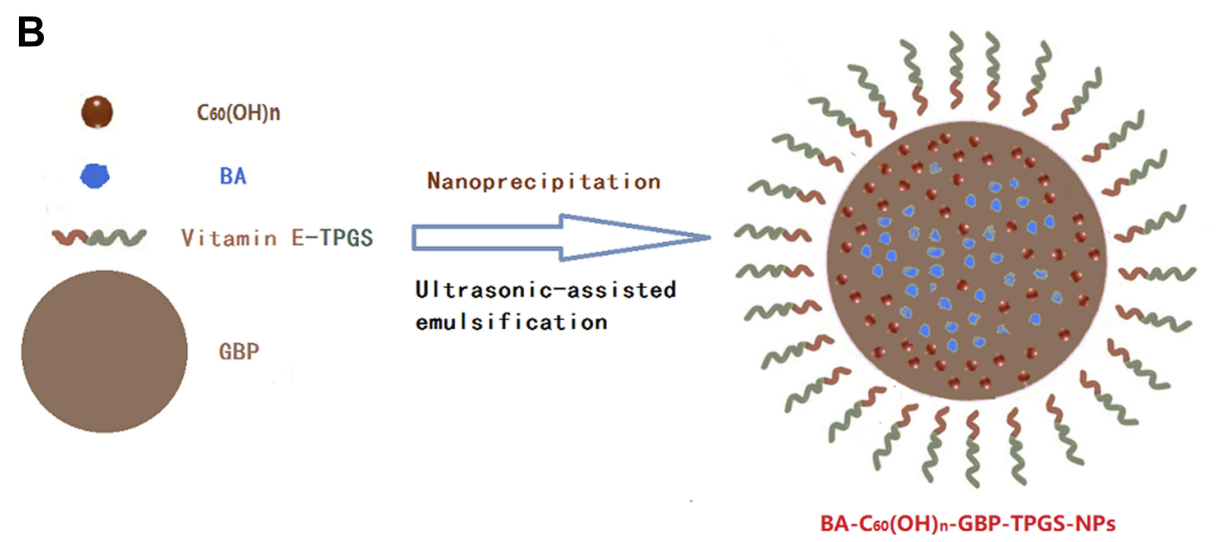

Figure I Illustration of the polyprenol lipid and vitamin E-TPGS-based core-shell type nanoparticles for betulinic acid and fullerenol delivery. (A) Chemical structure of betulinic acid and Ginkgo biloba leaves polyprenol. (B) Preparation scheme of BA- $\mathrm{C}_{60}(\mathrm{OH})_{\mathrm{n}}$-GBP-TPGS-NPs. 

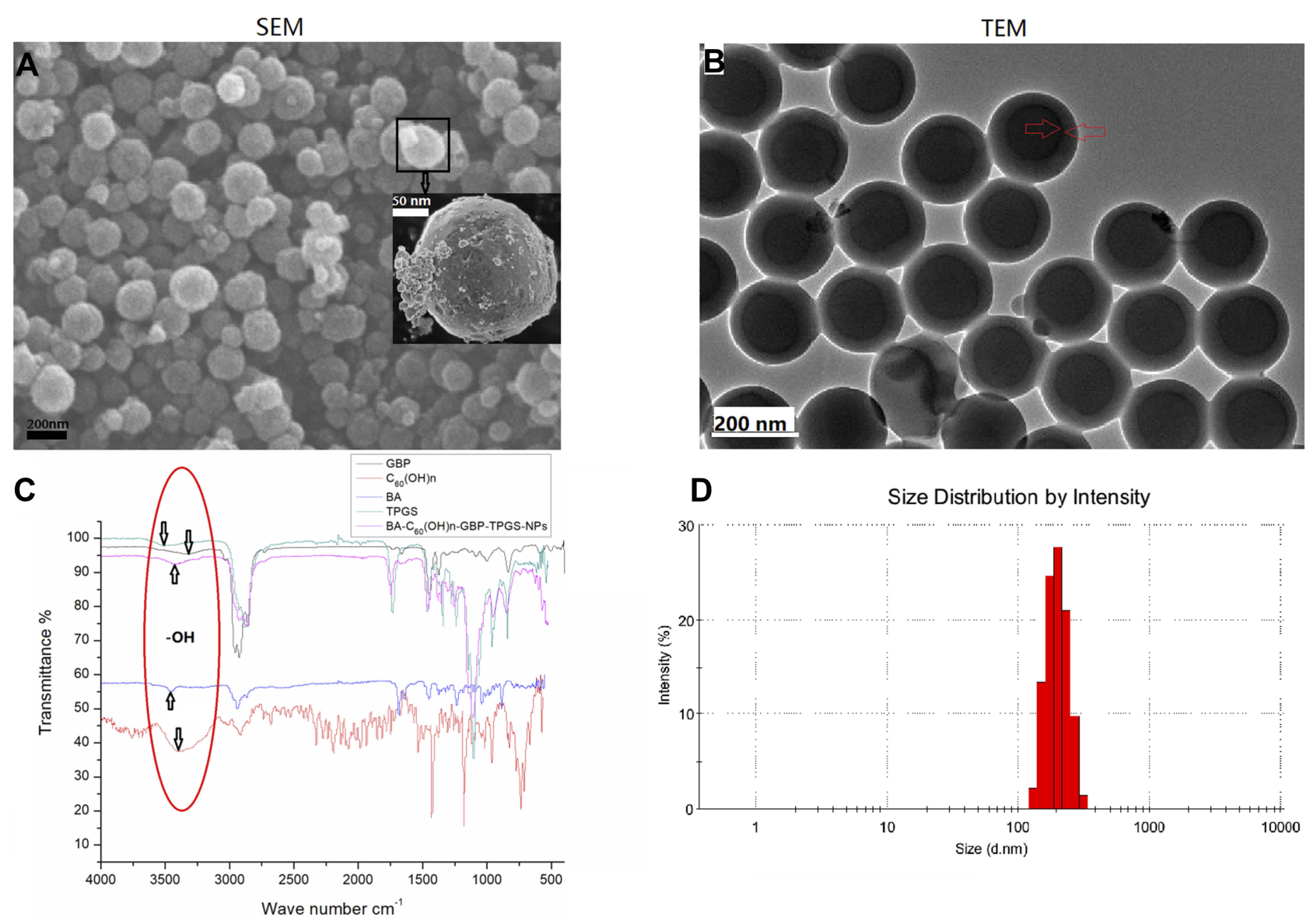

Figure 2 Characterization of BA-C ${ }_{60}(\mathrm{OH})_{n}$-GBP-TPGS-NPs. (A) SEM image. (B) TEM image. (C) FTIR spectrum. (D) Size distribution.

\section{In vitro Drug Release}

The in vitro release profile of $\mathrm{C}_{60}(\mathrm{OH})_{\mathrm{n}}$ versus $\mathrm{BA}-\mathrm{C}_{60}$ $(\mathrm{OH})_{\mathrm{n}}$-GBP-TPGS-NPs describes the release of up to $75 \%$ of the drug in the original burst within 5 hours, and the release is ensured by sustained release of the drug until 12 h. In contrast, the in vitro release profile of BA to NPs shows that up to $75 \%$ of the drug is released in 7 hours with weaker initial bursts, and is ensured by the continuous release of the drug up to 12 hours. It can be seen from Figure $3 \mathrm{~A}$ that the release process of $\mathrm{BA}$ and $\mathrm{C}_{60}$ $(\mathrm{OH})_{\mathrm{n}}$ from NPs at $\mathrm{pH} 6.5$ is too similar to that at $\mathrm{pH}$ 7.4. The results show that both $\mathrm{BA}$ and $\mathrm{C}_{60}(\mathrm{OH})_{\mathrm{n}}$ of NPs show a biphasic with sustained drug release characteristics release mode at $\mathrm{pH} 7.4$ and $\mathrm{pH} 6.5$.

\section{Stability Studies}

In independent experiments, aliquots were stored at $25^{\circ} \mathrm{C}$ and stability studies were performed during storage between 0 and 30 days. Stability studies were performed in simulated media at $0 \sim 24 \mathrm{~h}$ at $37^{\circ} \mathrm{C}$, pH 7.4 or $\mathrm{pH} 6.5$ buffer solution.
The results during storage (Figure 3B) showed no significant changes in the mean particle size of BA- $\mathrm{C}_{60}(\mathrm{OH})_{\mathrm{n}}$-GBPTPGS-NPs up to 30 days after PdI preparation $(\mathrm{p}>0.05)$. The results of the simulated medium in buffer solutions at pH 7.4 and pH 6.5 (Figure 3C) showed that the average particle size of NP and PdI did not change significantly until $24 \mathrm{~h}$ after preparation $(\mathrm{p}>0.05)$.

\section{Cytotoxicity}

In order to study the cytotoxicity of BA- $\mathrm{C}_{60}(\mathrm{OH})_{\mathrm{n}}-\mathrm{GBP}-$ TPGS-NP and a single drug from NPs, such as a mixture of $\mathrm{BA} / \mathrm{C}_{60}(\mathrm{OH})_{\mathrm{n}}$ with GBP and TPGS, MHCC97H and L02 cells were used to study the in vitro cytotoxicity. Compared to the TPGS solution, the developed formula has significantly higher cytotoxicity in $\mathrm{MHCC} 97 \mathrm{H}$ and L02 cell lines $(\mathrm{p}<0.05)$. As can be seen from Figure 4, BA- $\mathrm{C}_{60}(\mathrm{OH})_{\mathrm{n}}$-GBP-TPGS-NPs, BA-TPGS solution and $\mathrm{C}_{60}(\mathrm{OH})_{\mathrm{n}}$-TPGS dispersion inhibited the growth of MHCC97H and L02 cells at different doses. Concentration $(p<0.05)$. Depending on the concentration of cells treated with a dose of $\mathrm{BA} / \mathrm{C}_{60}(\mathrm{OH})_{\mathrm{n}}$ from 1 to 50 
$\mu \mathrm{g} / \mathrm{mL}$, the R\% of NPs treatment in MHCC97H and L02 cells increased from $49.8 \%$ to $94.8 \%$, from $4.4 \%$ to $29.2 \%$, respectively. In the case of the same $\mathrm{BA} / \mathrm{C}_{60}(\mathrm{OH})_{\mathrm{n}}$ concentration of BA-TPGS solution or $\mathrm{C}_{60}(\mathrm{OH})_{\mathrm{n}}$-TPGS dispersion, all $\mathrm{BA} / \mathrm{C}_{60}(\mathrm{OH})_{\mathrm{n}}$ concentrations of NPs showed higher inhibitory ability on $\mathrm{MHCC} 97 \mathrm{H}$ cells, and the cytotoxicity is low on L02 cells (MTT and LDH, $\mathrm{P}<0.05)$. In particular, low concentrations of $\mathrm{BA} / \mathrm{C}_{60}$ $(\mathrm{OH})_{\mathrm{n}}$ concentrations of NPs showed good inhibitory ability on MHCC97H cells (cell viability: $50.2 \%$ to $41.0 \%$ of the control, LDH release: $169.3 \%$ to $178.7 \%$ of the control). Low cytotoxicity of L02 cells (cells): $95.6 \%$ to $93.7 \%$, LDH release: $104.6 \%$ to $107.1 \%$ of the control).

\section{Cell Multiplication Assays and Cell Apoptosis Analysis}

In order to survey the sample's potential role in cell proliferation (Figure 5), a colony formation test was used. The results showed that by inhibiting BA- $\mathrm{C}_{60}(\mathrm{OH})_{\mathrm{n}}$-GBP-TPGS-NPs, the survival rate of colony formation in the doses of TPGS solution and $\mathrm{C}_{60}(\mathrm{OH})_{\mathrm{n}}$-TPGS dispersion in $\mathrm{MHCC} 97 \mathrm{H}$ cell line were significantly reduced depending on different $\mathrm{BA} / \mathrm{C}_{60}(\mathrm{OH})_{\mathrm{n}}$ concentrations $(\mathrm{P}<0.05)$. At all doses, the results show that at the same $\mathrm{BA} / \mathrm{C}_{60}(\mathrm{OH})_{\mathrm{n}}$ concentration, NPs have a greater ability to inhibit the proliferation of $\mathrm{MHCC} 97 \mathrm{H}$ cells than BATPGS solution and $\mathrm{C}_{60}(\mathrm{OH})_{\mathrm{n}}$-TPGS dispersion. Under the same $\mathrm{BA} / \mathrm{C}_{60}(\mathrm{OH})_{\mathrm{n}}$ concentration, the proliferation ability of L02 cells relative to the BA-TPGS solution and $\mathrm{C}_{60}(\mathrm{OH})_{\mathrm{n}^{-}}$ TPGS dispersion. Subsequently, flow cytometry analysis was performed to continue to detect whether apoptosis has affected the NPs on the proliferation of MHCC97H cells. The results show that $\mathrm{BA}^{-\mathrm{C}_{60}}(\mathrm{OH})_{\mathrm{n}}$-GBP-TPGS-NPs can obviously induce apoptosis of MHCC97H cells. In particular, high concentrations of NPs $\left(\mathrm{BA} / \mathrm{C}_{60}(\mathrm{OH})_{\mathrm{n}}: 50 \mu \mathrm{g} / \mathrm{mL}\right)$ have the strongest cell decay death induction ability.

\section{Genotoxic Effects}

The genotoxic effects of the aforementioned NPs were assessed by comet analysis. Compared with the TPGS solution, the tail DNA and tail moment of MHCC97H and L02
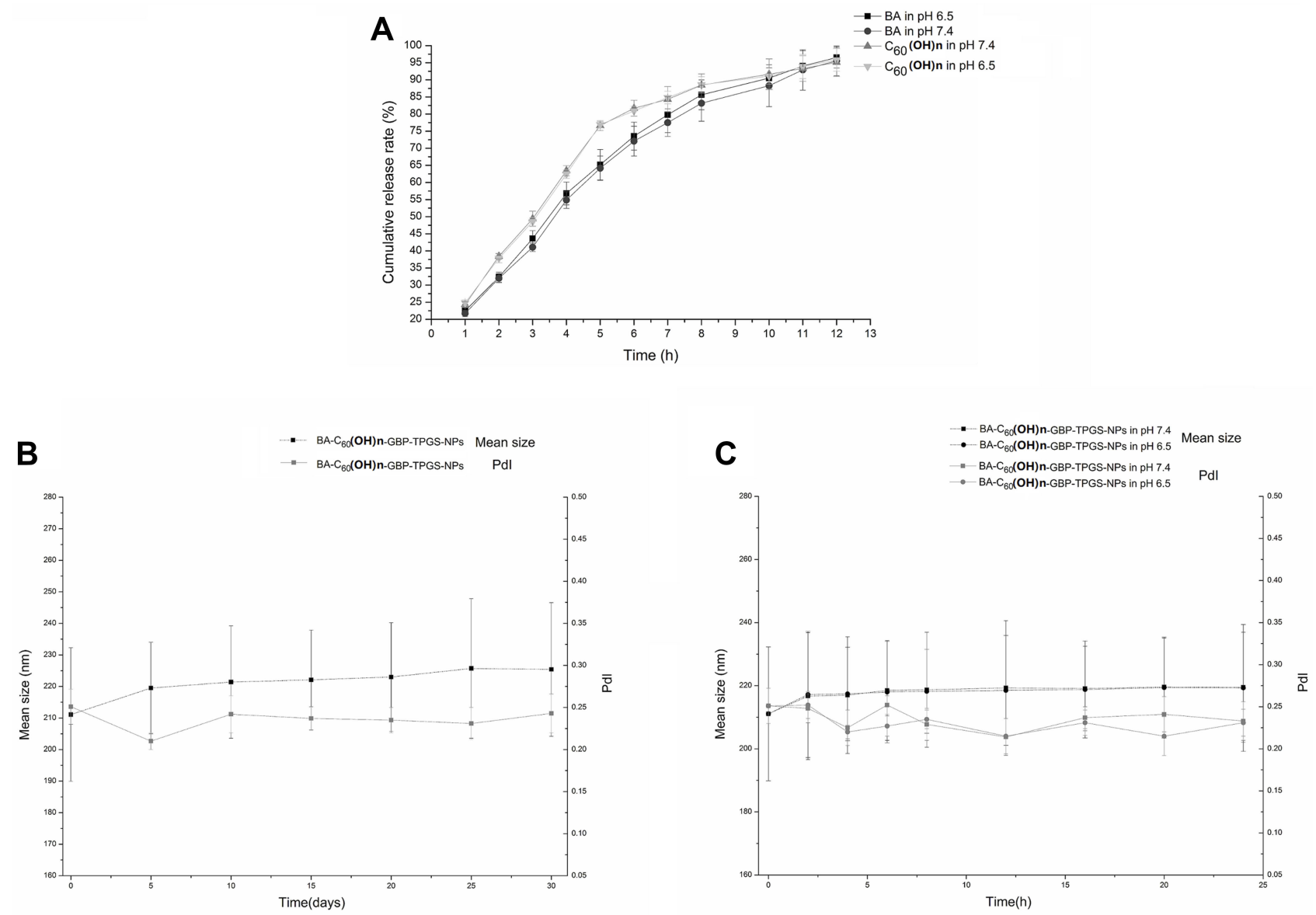

Figure 3 Drug release and stability of BA- $\mathrm{C}_{60}(\mathrm{OH})_{n}-\mathrm{GBP}-\mathrm{TPGS}-\mathrm{NPs}$. (A) Cumulative release profile of BA and $\mathrm{C}_{60}(\mathrm{OH})_{\mathrm{n}}$. $(\mathbf{B})$ Stability after preparation I-day storage. $(\mathbf{C})$ Stability after I-month storage. 

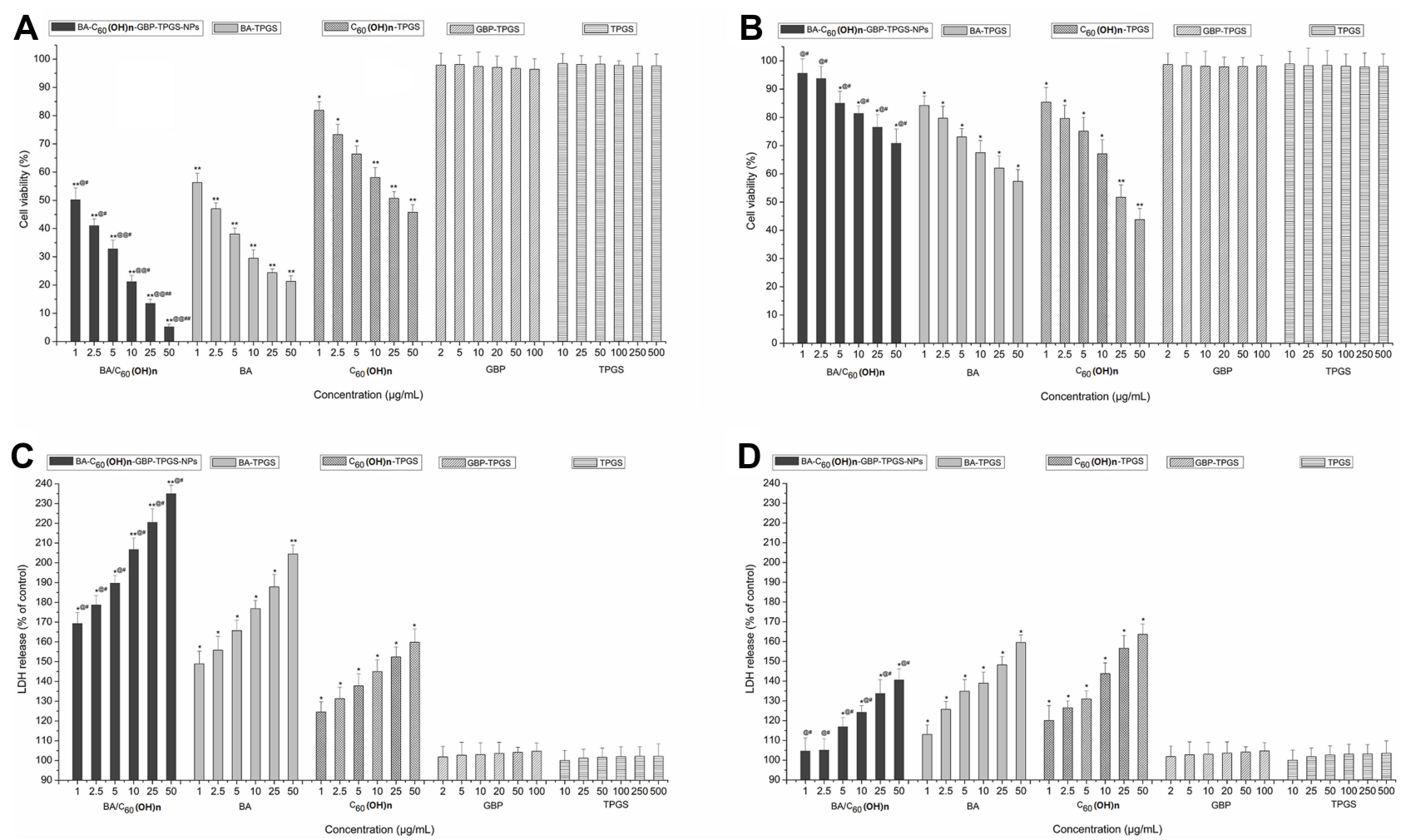

Figure 4 Cytotoxicity of different concentration samples on MHCC97H and L02 cells. (A) on MHCC97H, by MTT assay (B) on L02 cells, by MTT assay. (C) on MHCC97H, by LDH assay (D) on L02 cells, by LDH assay. ${ }^{*} \mathrm{p}<0.05,{ }^{*} \mathrm{p}<0.01$, versus viability or $\mathrm{LDH}$ release of cell treated with BA-C ${ }_{60}(\mathrm{OH})_{\mathrm{n}}-\mathrm{GBP}-\mathrm{TPGS}-\mathrm{NPs}, \mathrm{BA}-\mathrm{TPGS}$ or $\mathrm{C}_{60}(\mathrm{OH})_{\mathrm{n}}-\mathrm{TPGS}$ at the corresponding concentration of TPGS solution using Student's $t$-test. @ $\mathrm{P}<0.05$, @ @ ${ }_{\mathrm{p}}<0.0 \mathrm{I}$, versus viability or LDH release of cell treated with the NPs at the corresponding concentration of $\mathrm{C}_{60}(\mathrm{OH})_{n}$-TPGS using Student's $t$-test. ${ }^{\#} \mathrm{P}<0.05,{ }^{\#} \mathrm{p}<0.0 \mathrm{I}$, versus viability or $\mathrm{LDH}$ release of cell treated with the NPs at the corresponding concentration of BATPGS through the use of Student's $t$-test. Positive control was $20 \mu \mathrm{g} / \mathrm{mL}$ CDDP. The cell viabilities were under I\%. Values express mean \pm SD ( $\mathrm{n}=3$ ).

cells were measured for developed formulations, with statistically significant $(p<0.05)$ reduction (Figure 6 ) (representative photo of DNA damage, Figure 6E). Induced genotoxicity in MHCC $97 \mathrm{H}$ cells was traced to the positively induced doses of BA- $\mathrm{C}_{60}(\mathrm{OH})_{\mathrm{n}}$-GBP-TPGS-NPs, BA-TPGS solution and $\mathrm{C}_{60}$ $(\mathrm{OH})_{\mathrm{n}}$-TPGS dispersion in different concentration ranges immediate dose-response effects on the percentage of tail and tail moment in DNA. In addition, in MHCC97H and L02 cells, the genotoxic effect of the same concentration of NPs was significantly lower than that of BA-TPGS solution and $\mathrm{C}_{60}(\mathrm{OH})_{\mathrm{n}}$-TPGS dispersion. In particular, NPs with low $\mathrm{C} 60(\mathrm{OH}) \mathrm{n}$ concentrations showed lower genotoxicity (tail DNA on MHCC97H cells: $5.12 \%$, tail moment: 4.11; tail DNA on L02 cells: 5.07\%, tail moment: 4.23 ).

\section{In vitro Migration and Invasion Capability Inhibition}

The influence of $B A-\mathrm{C}_{60}(\mathrm{OH})_{\mathrm{n}}$-GBP-TPGS-NPs on MHCC97H cell migration and incursion was consistently to be assessed. In the present study, the migration of MHCC97H cells treated with all tested concentrations range doses of the
NPs, BA-TPGS solution and $\mathrm{C}_{60}(\mathrm{OH})_{\mathrm{n}}$-TPGS dispersion fluid was significantly reduced in a dose-dependent method relative to the contrast group (Figure 7A). At all doses, the research revealed that the NPs were higher inhibition lever of migration on MHCC97H cells compared with BA-TPGS solution and $\mathrm{C}_{60}(\mathrm{OH})_{\mathrm{n}}$-TPGS dispersion fluid at the same $\mathrm{BA} / \mathrm{C}_{60}(\mathrm{OH})_{\mathrm{n}}$ concentrations. Besides, the results of the cell invasion assay showed that all tested concentrations range doses of $\mathrm{BA}-\mathrm{C}_{60}$ $(\mathrm{OH})_{\mathrm{n}}$-GBP-TPGS-NPs, BA-TPGS solution and $\mathrm{C}_{60}(\mathrm{OH})_{\mathrm{n}^{-}}$ TPGS dispersion fluid obviously restrained the incursion capability of the MHCC97H cells in a dose-dependent method compared with the contrast group (Figure 7B). And at all doses, the study showed that the NPs were greater inhibition invasion on MHCC $97 \mathrm{H}$ cells compared with BA-TPGS solution and $\mathrm{C}_{60}(\mathrm{OH})_{\mathrm{n}}$-TPGS dispersion fluid at the same $\mathrm{BA} / \mathrm{C}_{60}$ $(\mathrm{OH})_{\mathrm{n}}$ concentrations.

\section{Western Blot Analysis}

In order to understand the mechanism of establishing antimetastatic properties of BA- $\mathrm{C}_{60}(\mathrm{OH})_{\mathrm{n}}$-GBP-TPGS-NPs, the signal pathways involved in the migration and invasion 


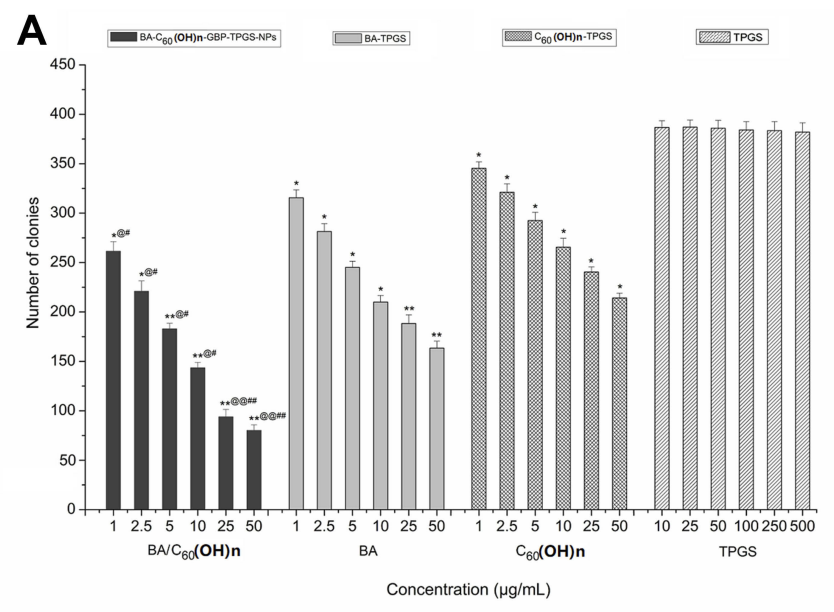

B

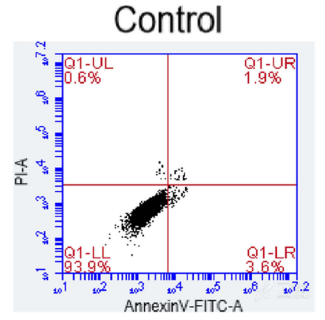

$10 \mu \mathrm{g} / \mathrm{mL}$

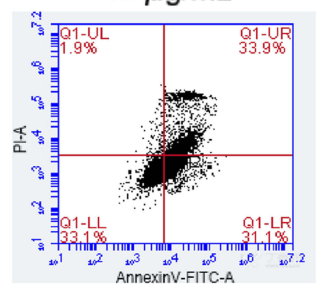

$1 \mu \mathrm{g} / \mathrm{mL}$

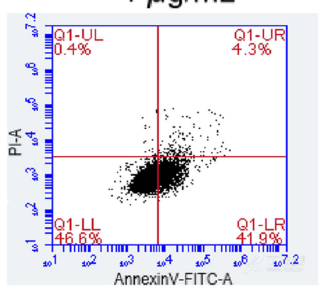

$50 \mu \mathrm{g} / \mathrm{mL}$

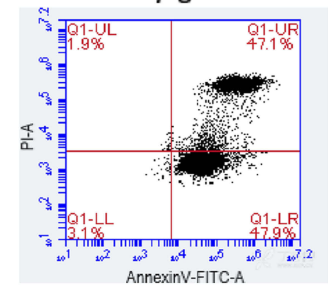

C

BA-TPGS

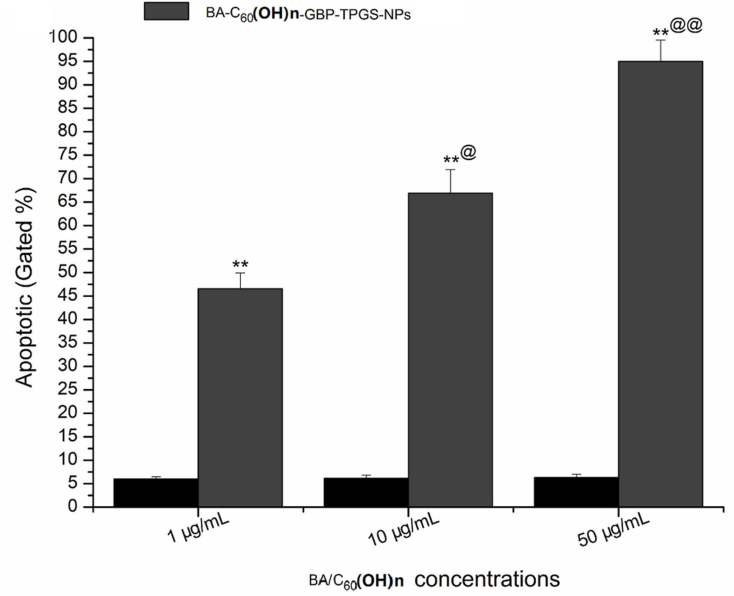

Figure $5 \mathrm{MHCC} 97 \mathrm{H}$ cells proliferation assays and apoptosis analysis. (A) Colony formation assay. ${ }^{\mathrm{p}}<0.05$, ** $<<0.01$, versus colony number of cells treated with $\mathrm{BA}-\mathrm{C}_{60}$ $(\mathrm{OH})_{n}$-GBP-TPGS-NPs, BA-TPGS or $\mathrm{C}_{60}(\mathrm{OH})_{n}$-TPGS at the corresponding concentration of TPGS solution using Student's $t$-test. @ $@_{\mathrm{P}}<0.05$, @@ $@_{\mathrm{P}}<0.0 \mathrm{I}$, versus colony number of cells treated with the NPs at the corresponding concentration of $\mathrm{C}_{60}(\mathrm{OH})_{n}$-TPGS using Student's $t$-test. ${ }^{\#}<<0.05$, ${ }^{\#} \mathrm{P}<0.0 \mathrm{I}$, versus colony number of cells treated with the NPs at the corresponding concentration of BA-TPGS using Student's t-test. (B, C) Flow-cytometer of cells stained with Annexin $\mathrm{V}$ and PI in MHCC97H cells with control (TPGS solution) or the NPs $\left(\mathrm{I}, 10\right.$ and $\left.50 \mu \mathrm{g} / \mathrm{mL} \mathrm{BA} / \mathrm{C}_{60}(\mathrm{OH})_{\mathrm{n}}\right)$. ${ }^{*}{ }_{\mathrm{p}}<0.0 \mathrm{I}$, versus apoptotic of cell treated with control or the NPs at the corresponding concentration of TPGS solution using Student's $t$-test. $@_{\mathrm{P}}<0.05$, @@ ${ }_{\mathrm{P}}<0.01$, versus apoptotic of cell treated with 10 or $50 \mu \mathrm{g} / \mathrm{mL}\left(\mathrm{BA} / \mathrm{C}_{60}(\mathrm{OH})_{\mathrm{n}}\right)$ of the NPs at the corresponding concentration of $1 \mu \mathrm{g} / \mathrm{mL}\left(\mathrm{BA} / \mathrm{C}_{60}(\mathrm{OH})_{\mathrm{n}}\right)$ of the NPs using Student's $t$-test.

of MHCC97H cells were examined by Western blot analysis after processing NPs with different $B A / \mathrm{C}_{60}(\mathrm{OH})_{n}$ concentrations $(1,10$, and $50 \mu \mathrm{g} / \mathrm{mL})$ for 24 hours. Compared with the control group, the mRNA expression of Caspase-3, Caspase- 8 and Caspase- 9 was significantly increased in cells treated with NP at 1,10 and $50 \mu \mathrm{g} / \mathrm{mL}$ $\left(\mathrm{BA} / \mathrm{C}_{60}(\mathrm{OH})_{\mathrm{n}}\right.$ concentration) (Figure $\left.8 \mathrm{~A}\right)$. Compared with the control group, protein expression of Caspase-3, Caspase- 8 and Caspase- 9 was significantly increased in cells treated with NP at 1,10 and $50 \mu \mathrm{g} / \mathrm{mL}\left(\mathrm{BA} / \mathrm{C}_{60}\right.$ $(\mathrm{OH})_{\mathrm{n}}$ concentration), respectively (Figure $\left.8 \mathrm{~B}\right)$. Overall, these results indicate that curing human liver tumor cells with moderate $\mathrm{BA} / \mathrm{C}_{60}(\mathrm{OH})_{\mathrm{n}}$ concentrations of $\mathrm{BA}-\mathrm{C}_{60}$ $(\mathrm{OH})_{\mathrm{n}}$-GBP-TPGS-NPs should effectively exceed
Caspase-3, Caspase- 8 and Caspase- 9 expression in MHCC97H cells.

\section{Discussions}

In this study, we prepared nanotechnology-related systems for loading two types of BA and low-substituted hydroxyl fullerenols. The NPs were developed by anti-solvent precipitation manner utilizing homogenization followed by ultra-sonication. Under acidic conditions, TPGS degradation is a problem due to the degradation of TPGS, which the stability is insufficient. ${ }^{32}$ Therefore, a neutral medium (such as ethyl acetate, DMSO or acetone) used to dissolve BA and $\mathrm{C}_{60}(\mathrm{OH})$ by neutral medium such as ethyl acetate, DMSO and acetone. The TEM outcomes and zeta 

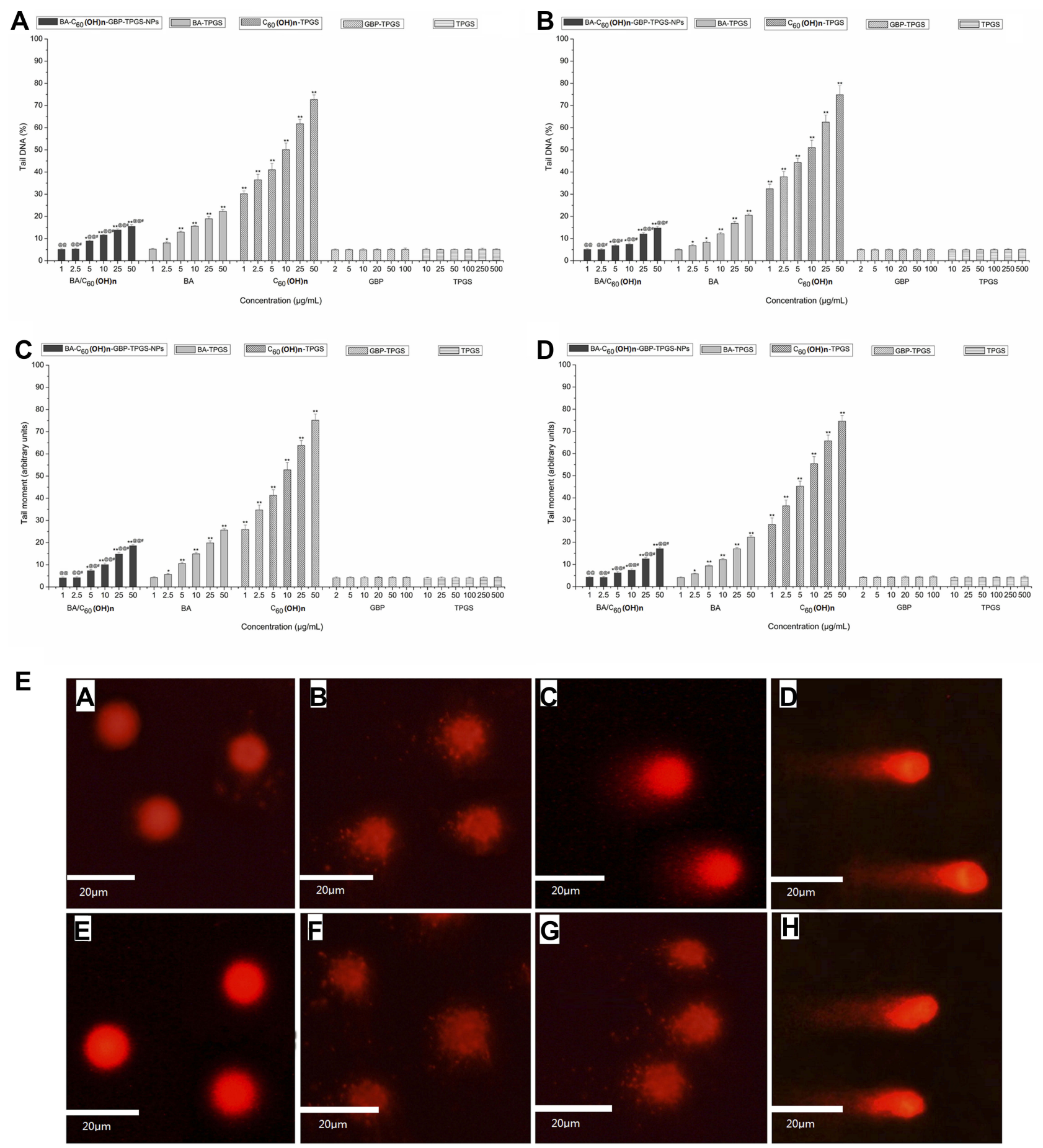

Figure 6 DNA damage detected by comet assay. (A) on MHCC97H, by tail DNA (B) on L02 cells, by tail DNA. (C) on MHCC97H, by tail moment (D) on L02 cells, by tail moment. ${ }^{*} p<0.05$, ** $p<0.0$, versus tail DNA or tail moment of cell treated with BA- $\mathrm{C}_{60}(\mathrm{OH})_{\mathrm{n}}$-GBP-TPGS-NPs, BA-TPGS or $\mathrm{C}_{60}(\mathrm{OH})_{\mathrm{n}}-\mathrm{TPGS}$ at the corresponding concentration of TPGS solution using Student's t-test. ${ }_{\mathrm{P}}<0.05$, $@_{\mathrm{P}}<0.01$, versus tail DNA or tail moment of cell treated with BA-C $\mathrm{C}_{60}(\mathrm{OH})_{\mathrm{n}}-\mathrm{GBP}-\mathrm{TPGS}-\mathrm{NPs}$ at the corresponding concentration of $\mathrm{C}_{60}(\mathrm{OH})_{n}$-TPGS using Student's $t$-test. ${ }^{*} \mathrm{p}<0.05$, versus tail DNA or tail moment of cell treated with BA-C $\mathrm{C}_{60}(\mathrm{OH})_{\mathrm{n}}$-GBP-TPGS-NPs at the corresponding concentration of BA-TPGS through the use of Student's $t$-test. Positive control was $50 \mathrm{mg} / \mathrm{mL} \mathrm{tBOOH}$. Tail DNA (\%) was above $95 \%$ and tail moment was above 98. Values express mean $\pm \mathrm{SD}(\mathrm{n}=3)$. E. Representative photos of DNA damage. $\mathrm{MHCC} 97 \mathrm{H}$ cells: a. negative control $\left(\mathrm{TPGS}\right.$ solution); b. I $\mu \mathrm{g} / \mathrm{mL}\left(\mathrm{BA} / \mathrm{C}_{60}(\mathrm{OH}) \mathrm{n}\right)$ of the NPs; c. $10 \mu \mathrm{g} / \mathrm{mL}\left(\mathrm{BA} / \mathrm{C}_{60}(\mathrm{OH})_{\mathrm{n}}\right)$ of the NPs; d. $50 \mu \mathrm{g} / \mathrm{mL}\left(\mathrm{BA} / \mathrm{C}_{60}(\mathrm{OH})_{\mathrm{n}}\right)$ of the NPs. L02 cells: e. control (TPGS solution); f. I $\mu \mathrm{g} / \mathrm{mL}\left(\mathrm{BA} / \mathrm{C}_{60}(\mathrm{OH})_{\mathrm{n}}\right)$ of the NPs; $\mathrm{g} .10$ $\mu \mathrm{g} / \mathrm{mL}\left(\mathrm{BA} / \mathrm{C}_{60}(\mathrm{OH})_{\mathrm{n}}\right)$ of the NPs; h. $50 \mu \mathrm{g} / \mathrm{mL}\left(\mathrm{BA} / \mathrm{C}_{60}(\mathrm{OH})_{\mathrm{n}}\right)$ of the NPs.

potential analysis revealed that $\mathrm{BA}-\mathrm{C}_{60}(\mathrm{OH})_{\mathrm{n}}-\mathrm{GBP}-\mathrm{TPGS}-$ NPs prepared were steady and well-dispersed in culture medium. From TEM, a circle of dark black within the particle should be the main distribution of $\mathrm{C}_{60}(\mathrm{OH})_{n}$ in the NPs. There were not enough hydroxyl groups on the $\mathrm{C}_{60}(\mathrm{OH})_{\mathrm{n}}$, induced to the presence of lipophilic inside of 

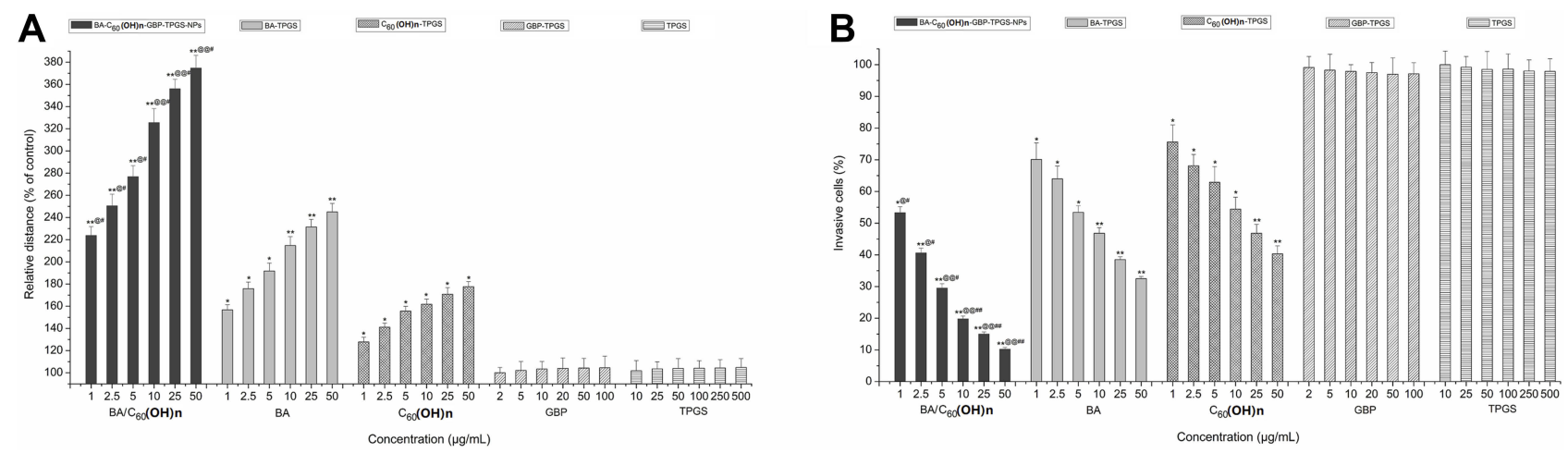

Figure 7 Migration and invasion capability inhibition. (A) MHCC97H cells migration by wound healing assay. (B) MHCC97H cells invasion by the $x$ CELLigence ${ }^{\circledR}$ DP system. ${ }^{*} \mathrm{p}<0.05$, ${ }^{* *} \mathrm{p}<0.01$, versus migration relative distance or invasive percentage of cell treated with BA-C ${ }_{60}(\mathrm{OH})_{\mathrm{n}}-\mathrm{GBP}-\mathrm{TPGS}-\mathrm{NPs}$, BA-TPGS or $\mathrm{C}_{60}(\mathrm{OH})_{\mathrm{n}}-\mathrm{TPGS}$ at the corresponding concentration of TPGS solution using Student's $t$-test. $@_{\mathrm{P}}<0.05$, @@ $@_{\mathrm{P}}<0.0 \mathrm{l}$, versus migration relative distance or invasive percentage of cell treated with $B A-C_{60}(O H)_{n}$-GBP-TPGS-NPs at the corresponding concentration of $C_{60}(O H)_{n}$-TPGS using Student's $t$-test. ${ }^{\#}<0.05$, \#\# $P<0.01$, versus migration relative distance or invasive percentage of cell treated with BA- $\mathrm{C}_{60}(\mathrm{OH})_{n}$-GBP-TPGS-NPs at the corresponding concentration of BA-TPGS using Student's $t$-test. Values present mean \pm SD $(n=3)$.

the NPs, rather than the outer hydrophilic layer. Besides, the infrared absorption peak of the NPs showed blue shifted slightly, possibly due to weak hydrogen bonding between the $\mathrm{C}_{60}(\mathrm{OH})_{\mathrm{n}}$ mixture and with GBP and BA. We inferred that the mixture of $\mathrm{C}_{60}(\mathrm{OH})_{\mathrm{n}}$ with different hydroxyl groups may have a certain effect on the stability of the NPs system itself.

Process and preparation variables have an important influence on the physical and chemical properties of NPs, which control the drug loading, drug release, cellular uptake and targeted delivery of NPs. ${ }^{33}$ Higher negative zeta potential can increase the chance of cellular uptake in the Reticulo Endothelial System (RES). ${ }^{34}$ PEGmodified nanoparticles usually have a charge shielding effect and lead to lower absolute values of zeta potential. $^{35}$ This phenomenon also exists in this study, so we performed a stability study in this study as a supplement. Due to the NP size range $(10 \sim 200 \mathrm{~nm})$, Endogenous RES cannot recognize these carriers, so NPs enhance permeability and retention (EPR) effects. ${ }^{36}$ However, the purpose is to make the $\mathrm{DE}$ of $\mathrm{BA} / \mathrm{C}_{60}$ $(\mathrm{OH})_{\mathrm{n}}$ higher, and the zeta potential is in batch $\mathrm{A}$ (higher zeta potential) and batch $\mathrm{E}$ (size: $10 \sim 200 \mathrm{~nm}$, higher DE and relative There is no significant difference between higher EE) and optimization). With the proportion of batch $\mathrm{E}$ (NPs is $20 \% \mathrm{GBP}$ ), $\mathrm{BA}$ and $\mathrm{C}_{60}(\mathrm{OH})_{\mathrm{n}}$ in BA- $\mathrm{C}_{60}(\mathrm{OH})_{\mathrm{n}}-\mathrm{GBP}-\mathrm{TPGS}-\mathrm{NPs}$ are likely to be saturated. Therefore, the optimized batch $\mathrm{E}$ of preparing NPs is reasonable for our next research. In this study of DE and EE, the prepared NPs had higher DE (both BA and $\mathrm{C}_{60}$
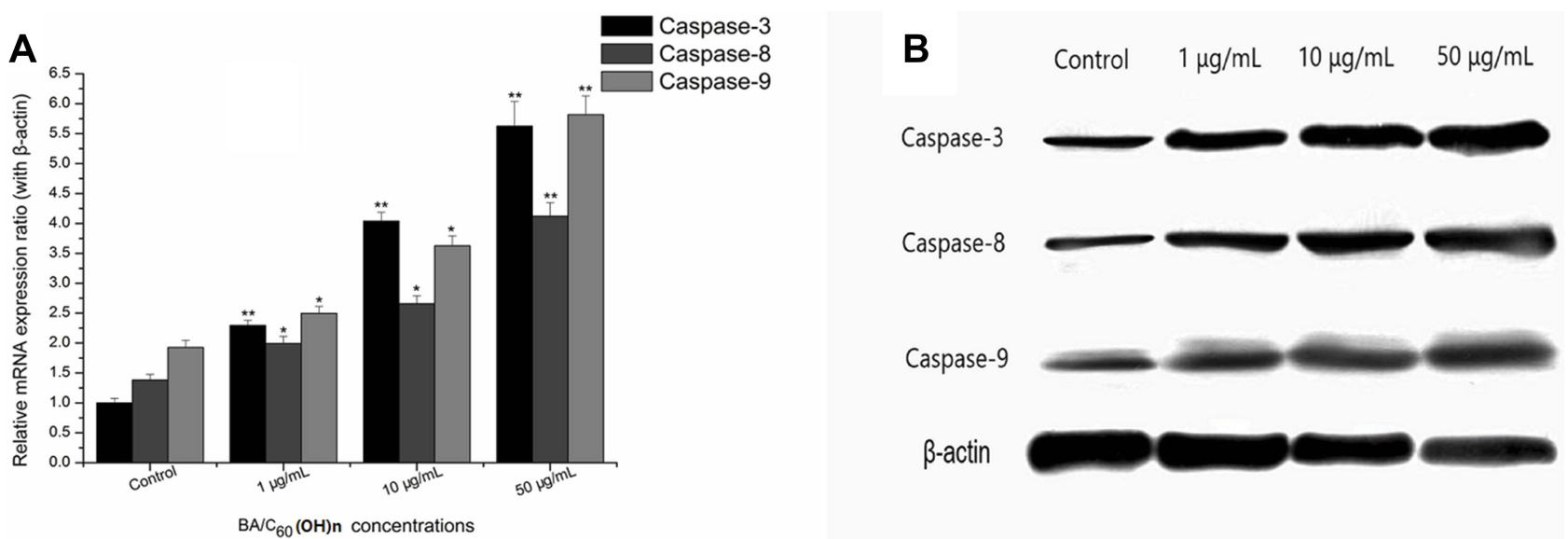

Figure 8 Effects of BA- $\mathrm{C}_{60}(\mathrm{OH})_{\mathrm{n}}$-GBP-TPGS-NPs treatment of MHCC97H cells on the expression levels of Caspase-3, Caspase-8 and Caspase-9. (A) Following treatment of MHCC97H cells with different concentrations of BA- $\mathrm{C}_{60}(\mathrm{OH})_{\mathrm{n}}$-GBP-TPGS-NPs for $24 \mathrm{~h}$, the mRNA expression levels of Caspase-3, Caspase-8 and Caspase-9 were tested by RT-qPCR. *p $<0.05$, **p $<0.0$, versus control using Student's $t$-test. (B) Western blotting showed the adjustment of protein by diverse concentration of BA- $\mathrm{C}_{60}$ $(\mathrm{OH})_{\mathrm{n}}$-GBP-TPGS-NPs on MHCC97H cells after $24 \mathrm{~h}$. 
$(\mathrm{OH})_{\mathrm{n}}$ exceeded $\left.17 \%\right)$ and $\mathrm{EE}\left(\mathrm{BA}\right.$ and $\mathrm{C}_{60}(\mathrm{OH})_{\mathrm{n}}$ both exceeded $85 \%$ ). Hydrophobic drugs.

The study on the release characteristics of $\mathrm{BA} / \mathrm{C}_{60}$ $(\mathrm{OH})_{\mathrm{n}}$ showed that the nano-system of $\mathrm{BA}-\mathrm{C}_{60}(\mathrm{OH})_{\mathrm{n}^{-}}$GBP-TPGS-NPs can maintain the release rate to 12 hours, which may be attributed to the internal lipid (GBP) and external stabilizer (TPGS) coatings, which have different thicknesses, leading to the initial high burst release. The second is a sustained release mode, which prolongs drug release from the NPs system and delays release from the core Absolute abrupt release. ${ }^{37}$ Compared with BA, the distribution of $\mathrm{C}_{60}(\mathrm{OH})_{\mathrm{n}}$ in the core of NPs is more external, which can also be supported in TEM. The release rate of $\mathrm{C}_{60}(\mathrm{OH})_{\mathrm{n}}$ is slightly faster than BA, but the trends between the two are similar. Controlling the release of NPs helps to overcome or reduce the multidrug resistance of HCC cells. ${ }^{38}$ This is very important for the preparation of anti-cancer NPs and is essential for the treatment of HCC diseases. Stability The test results show that BA- $\mathrm{C}_{60}(\mathrm{OH})_{\mathrm{n}}$-GBP-TPGS-NPs can keep stable performance for 30 days or 24 hours in the simulated medium. It is emphasized that in this study, BA- $\mathrm{C}_{60}(\mathrm{OH})_{\mathrm{n}}$-GBP-TPGS-NPs are both physically and chemically stable, which may be due to the drug core (the spherical nanocapsule structure of the $\mathrm{BA} / \mathrm{C}_{60}(\mathrm{OH})_{\mathrm{n}}$ ) is surrounded by lipids (GBP) and stabilizers (TPGS).

In this cytotoxicity study, it was found that in the same $\mathrm{BA} / \mathrm{C}_{60}(\mathrm{OH})_{\mathrm{n}}$ concentration, it showed higher inhibition ability for MHCC97H cells and lower cytotoxic effect on L02 cells by MTT assay and LDH assay. It is speculated that NPs containing TPGS and GBP can enhance inhibition of MHCC $97 \mathrm{H}$ cells treated with $\mathrm{BA} / \mathrm{C}_{60}(\mathrm{OH})_{\mathrm{n}}$ in GBP . The cytotoxicity of $\mathrm{C}_{60}(\mathrm{OH})_{\mathrm{n}}$ on various cells is significantly different. The genotoxicity of $\mathrm{C}_{60}(\mathrm{OH})_{\mathrm{n}}$ mainly depends on the cell size, dose and cell type. ${ }^{39}$ Based on this relationship between the hydroxyl value of fullerenol and cell membrane activity, the results include that $n \leq 2$ tends to penetrate into the cell membrane. $n \geq 8$ tends to adhere to the cell membrane; $\mathrm{n}=6$ tends to penetrate the entire cell membrane. ${ }^{16}$ This study involved the selection of $\mathrm{C}_{60}(\mathrm{OH})_{\mathrm{n}}$ mixtures with $\mathrm{n}=2-6, \mathrm{n}=$ 10-14, and $n=16-20$ to take full advantage of their different effects on cell membranes, thus showing better biological activity. Fullerenol-treated cells have significantly increased permeability and spread in HCC cells. ${ }^{40}$ In addition, polypentadiene can greatly improve the permeability and fluidity of cell membranes. ${ }^{12}$ The increased antitumor activity of NPs containing BA may be related to increased membrane permeability of fullerenol and GBP.

In this genotoxicity study, BA- $\mathrm{C}_{60}(\mathrm{OH})_{\mathrm{n}}$-GBP-TPGSNPs showed low genotoxicity to MHCC97H and L02 cells at low $\mathrm{BA} / \mathrm{C}_{60}(\mathrm{OH})_{\mathrm{n}}$ concentrations. Compared with other studies, ${ }^{41}$ the high concentration of fullerenol-TPGS complex in this study showed higher genotoxicity. The difference in cell permeability caused by fullerenols with different hydroxyl groups may be related to genetic toxicity. At the same time, from the results of NPs treatment, the cell migration capacity and invasion capacity of MHCC97H cells treated with NPs were significantly lower than those of the control group. Overall, the results showed that BA- $\mathrm{C}_{60}(\mathrm{OH})_{\mathrm{n}}$-GBP-TPGS-NPs inhibited the migration and invasion of $\mathrm{MHCC} 97 \mathrm{H}$ cells in vitro. Therefore, NPs can be a promising agent for anti-tumor therapy.

Apoptosis, migration and invasion of tumor cells are extremely complex and are regulated by multiple signaling pathways. In human cells, the apoptotic pathway can be divided into caspase-dependent branches. According to the substrate specificity and target protein of these caspases, they are related to apoptosis and can be divided into apoptotic promoter caspase 8 and apoptosis-influencing factor caspase $3 .^{42}$ Another caspase- 9 has been identified as a tumor cell with direct and critical targets that can transduce and mediate tumor cell proliferation, migration, and invasion through the apoptotic pathway. ${ }^{43}$ In previous studies, the results showed that BA can inhibit the proliferation of KM3 multiple myeloma cells and induce apoptosis in a time and dose-dependent manner, which is related to the activation of caspase- $3 .{ }^{44}$ Other results indicate that $\mathrm{BA}$ prevents the proliferation of $\mathrm{KB}$ cells and promotes mitochondrial apoptosis, indicating an increase in $\mathrm{TUNEL}^{+}$cells and the activity of caspase- 3 and caspase- $9 .{ }^{45}$ More importantly, it was found that the proteolytic level of lysed Caspase-3 in BA-treated HCC cells increased significantly, suggesting that BA induced tumor cell apoptosis through the inherent mitochondrial pathway. ${ }^{46}$ In addition, BA treatment can significantly increase its activity. Caspase- 3 and Caspase- 9 in DEN plus $\mathrm{CCl} 4$ treated mouse liver and HepG2 cells. Based on these results, BA induced significant apoptosis in both in vivo and in vitro HCC cells. ${ }^{47}$ These previous results are similar to the conclusions of this study, that $\mathrm{BA}-\mathrm{C}_{60}$ $(\mathrm{OH})_{\mathrm{n}}$-GBP-TPGS-NPs can effectively express Caspase-3, Caspase-8 and Caspase-9 in MHCC97H cells. Our results suggest that Caspase -3 , Caspase- 8 and Caspase- 9 may 
play an important role in the inhibition of HCC cells by NPs. It provided speculation that one of the important mechanisms of BA- $\mathrm{C}_{60}(\mathrm{OH})_{\mathrm{n}}$-GBP-TPGS-NPs inhibiting MHCC97H cells may be by up-regulating the expression of Caspase-3, Caspase- 8 and Caspase-9. However, upregulating the expression of Caspase- 3 , Caspase- 8 and Caspase-9 is the main factor that inhibits HCC and needs further study.

Metastasis is the main cause of high morbidity and mortality of liver cancer. The process of allowing tumor cells to migrate and invade is an important therapeutic goal. Cell migration does not require caspase. However, they can affect signaling pathways that promote migration and enhance migration, either as part of the normal caspase cascade sub-apoptotic activation or due to the noncatalytic activity of caspase- 8 in higher organisms. ${ }^{48}$ Caspase- 8 is a key upstream trigger for programmed cell death, but paradoxically, there is evidence that caspase- 8 can promote cell migration. ${ }^{49}$ From the results of this study, there was no significant increase in Caspase- 8 in cells treated with BA- $\mathrm{C}_{60}(\mathrm{OH})_{\mathrm{n}}$-GBP-TPGS-NPs compared to Caspase-3 and Caspase-9. Therefore, we speculated that down-regulating the expression of Caspase- 8 in HCC cell migration may attenuate the effect of upregulating the expression of Caspase- 8 in $B A-\mathrm{C}_{60}(\mathrm{OH})_{\mathrm{n}^{-}}{ }^{-}$ GBP-TPGS-NPs and promote the apoptosis of liver cancer cells.

\section{Conclusions}

In this study, it involves a newer formulation that includes the polypentadiene lipids and vitamin E-TPGS hybrid nanoparticles for controlled release of betulinic acid and low-substituted hydroxyl fullerenol, and successfully developed BA- $\mathrm{C}_{60}(\mathrm{OH})_{\mathrm{n}}$-GBP-TPGS-NPs delivery system, and its anti-HCC effects were researched. In conclusion, NPs exhibited improved solubility and stability. NPs showed significant internal and external boundaries, and the distribution of drug-loaded also had obvious regularity, especially the distribution of $\mathrm{C}_{60}(\mathrm{OH})_{\mathrm{n}}$. The NPs have high $\mathrm{DE}$ and high $\mathrm{EE}$ of $\mathrm{BA}$ and $\mathrm{C}_{60}(\mathrm{OH})_{\mathrm{n}}$. $\mathrm{BA}$ and $\mathrm{C}_{60}$ $(\mathrm{OH})_{\mathrm{n}}$ for NPs displayed a biphasic release pattern with sustained drug release characteristics.

In this bioactivity study, BA- $\mathrm{C}_{60}(\mathrm{OH})_{\mathrm{n}}$-GBP-TPGSNPs could effectively inhibit proliferation, migration and invasion of $\mathrm{MHCC} 97 \mathrm{H}$ cell in vitro. We concluded that one of the important mechanisms by which BA- $\mathrm{C}_{60}(\mathrm{OH})_{\mathrm{n}^{-}}-$ GBP-TPGS-NPs inhibit MHCC97Hcells may be achieved by up-regulating the expression of Caspase-3, Caspase- 8 and Caspase-9. However, we need to add a few inferences that down-regulating Caspase-8 expression of $\mathrm{BA}-\mathrm{C}_{60}$ $(\mathrm{OH})_{\mathrm{n}}$-GBP-TPGS-NPs inhibiting HCC cell migration may reduce the effect of up-regulating the NPs to promote Caspase- 8 expression and HCC cell apoptosis.

All these results indicate that $B A-C_{60}(\mathrm{OH})_{n}-\mathrm{GBP}-$ TPGS-NPs effectively inhibits the HCC deterioration and is expected to play an important role in the treatment of HCC. We infer that a mixture of $\mathrm{C}_{60}(\mathrm{OH})_{\mathrm{n}}$ with different hydroxyl groups may have some impact on the stability of the NPs system itself. Meanwhile, combined use of $\mathrm{C}_{60}$ $(\mathrm{OH})_{\mathrm{n}}$ and BA in GBP lipids may increase the inhibit effect of $\mathrm{C}_{60}(\mathrm{OH})_{n}$ or BA against $\mathrm{HCC}$ cells and reduce cytotoxicity and genotoxicity of $\mathrm{C}_{60}(\mathrm{OH})_{\mathrm{n}}$ for ordinary cells. In particular, the relationship between the physicochemical regularities and biological activities of lowsubstituted hydroxyl fullerenol in GBP is worthy of further research and development.

\section{Acknowledgments}

This work was supported by the National Nonprofit Institute Research Grant of CAFINT (No. CAFYBB2016SY030 and No. CAFYBB2018GA001), the Key Laboratory of Biomass Energy and Materials Project of Jiangsu Province of China (JSBEM-S-202008) and the Research Team Building Innovation Project of ICIFP (No. LHSXKQ5).

\section{Disclosure}

The authors declare no conflict of interest.

\section{References}

1. Saneja A, Sharma L, Dubey RD, et al. Synthesis, characterization and augmented anticancer potential of PEG-betulinic acid conjugate. Mat Sci Eng C-Mater. 2017;73:616-626. doi:10.1016/j.msec.2016.12.109

2. Saneja A, Kumar R, Mintoo MJ, et al. Gemcitabine and betulinic acid co-encapsulated PLGA-PEG polymer nanoparticles for improved efficacy of cancer chemotherapy. Mat Sci Eng C-Mater. 2019;98:764-771. doi:10.1016/j.msec.2019.01.026

3. Ali-Seyed M, Jantan I, Vijayaraghavan K, Bukhari SNA. Betulinic acid: recent advances in chemical modifications, effective delivery, and molecular mechanisms of a promising anticancer therapy. Chem Biol Drug Des. 2016;87:517-536. doi:10.1111/cbdd.12682

4. Zhang DM, Xu HG, Wang L, et al. Betulinic acid and its derivatives as potential antitumor agents. Med Res Rev. 2015;35:1127-1155. doi:10.1002/med.21353

5. Dai L, Wang L, Deng L, et al. Novel multiarm polyethylene glycol-dihydroartemisinin conjugates enhancing therapeutic efficacy in non-small-cell lung cancer. Sci Rep. 2014;4:5871. doi:10.1038/ srep05871

6. Di Cagno M, Stein PC, Styskala J, Hlavác` J, Skalko-Basnet N, BauerBrandl A. Overcoming instability and low solubility of new cytostatic compounds: a comparison of two approaches. Eur J Pharm Biopharm. 2012;80:657-662. doi:10.1016/j.ejpb.2011.11.016 
7. Guo Y, Luo J, Tan S, Otieno BO, Zhang Z. The applications of Vitamin E TPGS in drug delivery. Eur $J$ Pharm Sci. 2013;49:175-186. doi:10.1016/j.ejps.2013.02.006

8. Yang C, Wu T, Qi Y, Zhang Z. Recent advances in the application of vitamin E TPGS for drug delivery. Theranostics. 2018;8:464-485. doi:10.7150/thno.22711

9. Tao R, Wang CZ, Ye JZ, Zhou H, Chen HX, Zhang CW. Antibacterial, cytotoxic and genotoxic activity of nitrogenated and haloid derivatives of C50-C60 and C70-C120 polyprenol. Lipids Health Dis. 2016;15:175. doi:10.1186/s12944-016-0345-x

10. Xu HB, He L, Liu GQ, Li HT, Wang CZ. The reversal of P-glycoprotein-mediated MDR by GP associated with chemotherapeutic drugs. Chinese Pharm Bull. 2007;23:1207-1212.

11. Tao R, Wang CZ, Zhang CW, et al. Characterization, cytotoxicity and genotoxicity of graphene oxide and folate coupled chitosan nanocomposites loading polyprenol and fullerene based nanoemulsion against MHCC97H cells. J Biomed Nanotechnol. 2019;15:555-570. doi:10.1166/jbn.2019.2698

12. Ciepichal E, Jemiola-Rzeminska M, Hertel J, Swiezewska E, Strzalka K. Configuration of polyisoprenoids affects the permeability and thermotropic properties of phospholipids/polyisoprenoid model membranes. Chem Phys Lipids. 2011;164:300-306. doi:10.1016/j. chemphyslip.2011.03.004

13. Tan S, Zou C, Zhang W, Yin M, Gao X. Recent developments in d- $\alpha-$ tocopheryl polyethylene glycol-succinate-based nanomedicine for cancer therapy. Drug Deliv. 2017;24:1831-1842. doi:10.1080/ 10717544.2017.1406561

14. Meng H, Xing GM, Sun BY, et al. Potent angiogenesis inhibition by the particulate form of fullerene derivatives. ACS Nano. 2010;4:2773-2783. doi:10.1021/nn100448z

15. Prylutska SV, Burlaka AP, Prylutskyy YI, Ritter U, Scharff P. Pristine C(60) fullerenes inhibit the rate of tumor growth and metastasis. Exp Oncol. 2011;33:162-164.

16. Nakamura H, Nozaki Y, Koizumi Y, Watano S. Effect of number of hydroxyl groups of fullerenol $\mathrm{C} 60(\mathrm{OH}) \mathrm{n}$ on its interaction with cell membrane. J Taiwan Inst Chem E. 2018;90:18-24. doi:10.1016/j. jtice.2017.11.016

17. Eropkin MY, Melenevskaya EY, Nasonova KV, et al. Synthesis and biological activity of fullerenols with various contents of hydroxyl groups. Pharm Chem J. 2013;47:87-91. doi:10.1007/s11094-013-0901-x

18. Yan A, Von Dem Bussche A, Kane AB, Hurt RH. Tocopheryl polyethylene glycol succinate as a safe, antioxidant surfactant for processing carbon nanotubes and fullerenes. Carbon. 2007;45:2463-2470. doi:10.1016/j.carbon.2007.08.035

19. Zheng Y, You X, Guan S, et al. Poly (ferulic acid) with an anticancer effect as a drug nanocarrier for enhanced colon cancer therapy. $A d v$ Funct Mater. 2019;29:1808646. doi:10.1002/adfm.201808646

20. Li P, Wang Y, Zeng F, Chen L, Peng Z, Kong L-X. Synthesis and characterization of folate conjugated chitosan and cellular uptake of its nanoparticles in HT-29 cells, Carbohydr. Res. 2011;346:801-806.

21. Ly TU, Tran NQ, Hoang TK, Phan KN, Truong HN. Pegylated dendrimer and its effect in fluorouracil loading and release for enhancing antitumor activity. J Biomed Nanotechnol. 2013;9:213-220. doi:10.1166/jbn.2013.1479

22. Merlin JP, Rajendra Prasad N, Shibli SMA, Sebeela M. Ferulic acid loaded Poly-D, L-lactide-co-glycolide nanoparticles: systematic study of particle size, drug encapsulation efficiency and anticancer effect in non-small cell lung carcinoma cell line in vitro. Biomed.Prev Nutr. 2012;2:69-76. doi:10.1016/j.bionut.2011.12.007

23. Zhao GL, Yan WD, Cao D. Simultaneous determination of betulin and betulinic acid in white birch bark using RP-HPLC. J.pharm Biomed. 2007;43:959-962. doi:10.1016/j.jpba.2006.09.026

24. Tao R, Wang CZ, Kong ZW. Antibacterial/antifungal activity and synergistic interactions between polyprenols and other lipids isolated from Ginkgo biloba L. leaves. Molecules. 2013;18:2166-2182. doi: $10.3390 /$ molecules 18022166
25. Hare JP, Kroto HW, Taylor R. Preparation and UV/visible spectra of fullerenes C60 and C70. Chem Phys Lett. 1991;177:394-398. doi:10.1016/0009-2614(91)85072-5

26. Tengchaisri T, Chawengkirttikul R, Rachaphaew N, Reutrakul V, Sangsuwan R, Sirisinha S. Antitumor activity of triptolide against cholangiocarcinoma growth in vitro and in hamsters. Cancer Lett. 1998;133:169-175. doi:10.1016/S0304-3835(98)00222-5

27. Alarifi S, Ali D, Alkahtani S, Alhader MS. Iron oxide nanoparticles induce oxidative stress, DNA damage, and caspase activation in the human breast cancer cell line. Biol Trace Elem Res. 2014;159:416-424. doi:10.1007/s12011-014-9972-0

28. Ali D, Ray RS, Hans RK. UVA-induced cytotoxicity and DNA damaging potential of benz(e) acephenanthrylene. Toxicol Lett. 2010;199:193-200. doi:10.1016/j.toxlet.2010.08.023

29. Nowak-Sliwinska P, van Beijnum JR, Casini A, et al. Organometallic ruthenium(II) arene compounds with antiangiogenic activity. $J$ Med Chem. 2011;54:3895-3902. doi:10.1021/jm2002074

30. Hickok JR, Sahni S, Mikhed Y, Bonini MG, Thomas DD. Nitric oxide suppresses tumor cell migration through N-Myc downstream-regulated gene-1 (NDRG1) expression: role of chelatable iron. J Biol Chem. 2011;286:41413-41424. doi:10.1074/jbc.M111.287052

31. Livak KJ, Schmittgen TD. Analysis of relative gene expression data using real-time quantitative PCR and the 2(-Delta Delta C(T)) method. Methods. 2001;25:402-408. doi:10.1006/meth.2001.1262

32. Mi Y, Liu Y, Feng SS. Formulation of docetaxel by folic acid-conjugated $\mathrm{d}$ - $\alpha$-tocopheryl polyethylene glycol succinate 2000 (vitamin E TPGS 2k) micelles for targeted and synergistic chemotherapy. Biomaterials. 2011;32:4058-4066. doi:10.1016/j.biomaterials.2011.02.022

33. Katiyar SS, Kushwah V, Dora CP, Jain S. Lipid and TPGS based novel core-shell type nanocapsular sustained release system of methotrexate for intravenous application. Colloid Surface B. 2019;174:501-510. doi:10.1016/j.colsurfb.2018.11.053

34. He C, Hu Y, Yin L, Tang C, Yin C. Effects of particle size and surface charge on cellular uptake and biodistribution of polymeric nanoparticles. Biomaterials. 2010;31:3657-3666. doi:10.1016/j. biomaterials.2010.01.065

35. Takahashi T, Yamada Y, Kataoka K, Nagasaki Y. Preparation of a novel PEG-clay hybrid as a DDS material: dispersion stability and sustained release profiles. $J$ Control Release. 2005;107:408-416. doi:10.1016/j.jconrel.2005.03.031

36. Meng H, Xue M, Xia T, et al. Use of size and a copolymer design feature to improve the biodistribution and the enhanced permeability and retention effect of doxorubicin-loaded mesoporous silica nanoparticles in a murine xenograft tumor model. ACS Nano. 2011;5:4131-4144. doi:10.1021/nn200809t

37. Burger KN, Staffhorst RW, de Vijlder HC, et al. Nanocapsules: lipid-coated aggregates of cisplatin with high cytotoxicity. Nat Med. 2002;8:81-84. doi:10.1038/nm0102-81

38. Chi X, Yin Z, Jin J, Li H, Gao J. Arsenite-loaded nanoparticles inhibit invasion and metastasis of hepatocellular carcinoma: in vitro and in vivo study. Nanotechnology. 2017;28:445101. doi:10.1088/ 1361-6528/aa8791

39. Su Y, Xu JY, Shen P, et al. Cellular uptake and cytotoxic evaluation of fullerenol in different cell lines. Toxicology. 2010;269:155-159. doi:10.1016/j.tox.2009.11.015

40. Zhu X, Wang Z, Liu X. Investigation of effect of fullerenol on viscoelasticity properties of human hepatocellular carcinoma by AFM-based creep tests. J Mater Res. 2017;32:2521-2531. doi:10.1557/jmr.2017.229

41. Prylutska S, Politenkova S, Afanasieva K, et al. A nanocomplex of C60 fullerene with cisplatin: design, characterization and toxicity. Beilstein J Nanotech. 2017;8:1494-1501. doi:10.3762/bjnano.8.149

42. Chang YJ, Tai CJ, Kuo LJ, et al. Glucose-regulated protein 78 (GRP78) mediated the efficacy to curcumin treatment on hepatocellular carcinoma. Ann Surg Oncol. 2011;18:2395-2403. doi:10.1245/ s10434-011-1597-3 
43. Zhang L, Zhang X, Wang X, He M, Qiao S. MicroRNA-224 promotes tumorigenesis through downregulation of caspase-9 in triple-negative breast cancer. Dis Markers. 2019;2019:7378967.

44. Zhang X, Hu J, Chen Y. Betulinic acid and the pharmacological effects of tumor suppression (review). Mol Med Rep. 2016;14:4489-4495. doi:10.3892/mmr.2016.5792

45. Shen H, Liu L, Yang Y, Xun W, Wei K, Zeng G. Betulinic acid inhibits cell proliferation in human oral squamous cell carcinoma via modulating ros-regulated p53 signaling. Oncol Res. 2017;25:1141-1152. doi:10.3727/096504017X14841698396784

46. Eichenmüller M, von Schweinitz D, Kappler R. Betulinic acid treatment promotes apoptosis in hepatoblastoma cells. Int $J$ Oncol. 2009;35:873-879. doi:10.3892/ijo_00000402
47. Yang J, Qiu B, Li X, Zhang H, Liu W. P53-p66shc/mir-21-sod2 signaling is critical for the inhibitory effect of betulinic acid on hepatocellular carcinoma. Toxicol Lett. 2015;3:1-10. doi:10.1016/j. toxlet.2015.07.016

48. Keller N, Ozmadenci D, Ichim G, Stupack D. Caspase-8 function, and phosphorylation, in cell migration. Semin Cell Dev Biol. 2018;82:105-117. doi:10.1016/j.semcdb.2018.01.009

49. Barbero S, Barila D, Mielgo A, Stagni V, Clair K, Stupack D. Identification of a critical tyrosine residue in caspase 8 that promotes cell migration. J Biol Chem. 2008;283:13031-13034. doi:10.1074/ jbc.M800549200

\section{Publish your work in this journal}

The International Journal of Nanomedicine is an international, peerreviewed journal focusing on the application of nanotechnology in diagnostics, therapeutics, and drug delivery systems throughout the biomedical field. This journal is indexed on PubMed Central, MedLine, CAS, SciSearch ${ }^{\circledR}$, Current Contents ${ }^{\mathbb{B}} /$ Clinical Medicine,
Journal Citation Reports/Science Edition, EMBase, Scopus and the Elsevier Bibliographic databases. The manuscript management system is completely online and includes a very quick and fair peer-review system, which is all easy to use. Visit http://www.dovepress.com/ testimonials.php to read real quotes from published authors. 